\title{
Riverine flood plains: present state and future trends
}

\author{
KLEMENT TOCKNER ${ }^{1 *}$ AND JACK A. STANFORD ${ }^{2}$ \\ ${ }^{I}$ Department of Limnology, EAWAG/ETH, 8600 Dübendorf, Smitzerland and ${ }^{2}$ Flathead Lake Biological Station, The University of Montana, \\ 311 Bio Station Lane, Polson, MT, USA
}

Date submitted: 19 October 2001 Date accepted: 10 April 2002

Dedicated in Memoriam to Professor Gernot Bretschko

\section{SUMMARY}

Natural flood plains are among the most biologically productive and diverse ecosystems on earth. Globally, riverine flood plains cover $>2 \times 10^{6} \mathrm{~km}^{2}$, however, they are among the most threatened ecosystems. Floodplain degradation is closely linked to the rapid decline in freshwater biodiversity; the main reasons for the latter being habitat alteration, flow and flood control, species invasion and pollution. In Europe and North America, up to $\mathbf{9 0 \%}$ of flood plains are already 'cultivated' and therefore functionally extinct. In the developing world, the remaining natural flood plains are disappearing at an accelerating rate, primarily as a result of changing hydrology. Up to the 2025 time horizon, the future increase of human population will lead to further degradation of riparian areas, intensification of the hydrological cycle, increase in the discharge of pollutants, and further proliferation of species invasions. In the near future, the most threatened flood plains will be those in south-east Asia, Sahelian Africa and North America. There is an urgent need to preserve existing, intact flood plain rivers as strategic global resources and to begin to restore hydrologic dynamics, sediment transport and riparian vegetation to those rivers that retain some level of ecological integrity. Otherwise, dramatic extinctions of aquatic and riparian species and of ecosystem services are faced within the next few decades.

Keymords: conservation, restoration, catchment, biodiversity, connectivity, wetland, climate change

\section{INTRODUCTION}

Riverine flood plains are among the Earth's most distinctive landscape features. In the natural state they are characterized by high biodiversity and productivity, and corresponding recreational and aesthetic values. Flood plains are of great cultural and economic importance; early civilizations arose in

* Correspondence: Dr Klement Tockner e-mail: tockner@eawag.ch fertile flood plains and throughout history people have learned to cultivate and use their rich resources. Riverine flood plains have also served as focal points for urban development and exploitation of their natural functions.

Several comprehensive books on flood plains have been published during the last 20 years, including monographs on the Pongolo flood plain (South Africa; Heeg \& Bren 1982), the Hadejia-Nguru flood plain (Nigeria; Hollis et al. 1993), the Gearagh (a small anastomosing river in Ireland; Brown et al. 1995), the Luznice (a small meandering river-floodplain system in the Czech Republic; Prach et al. 1996), the Amazon (South America; Junk 1997), the Pantanal (South America; Heckman 1998), Czech flood plains and the effects of water management (Penka et al. 1985, 1991) and British flood plains (Bailey et al. 1998). Further, there are textbooks on floodplain fisheries (Welcomme 1975, 1979), on forested wetlands including flood plains (Lugo et al. 1990) on floodplain processes (Anderson et al. 1996), on the geomorphology of lowland rivers (Carling \& Petts 1992), on macroinvertebrates in North American flood plains and wetlands (Batzer et al. 1999), on biodiversity in wetlands and flood plains (Gopal et al. 2000, 2002), on wetland ecology and management (Mitsch \& Gosselink 2000), on European floodplain forests (Klimo \& Hager 2001), and on the restoration of riverfloodplain systems (Middleton 1999; Smits et al. 2000).

Flood plains, with an estimated global extent ranging from $0.8 \times 10^{6} \mathrm{~km}^{2}$ to $2 \times 10^{6} \mathrm{~km}^{2}$ (Mitsch \& Gosselink 2000; Ramsar \& IUCN [World Conservation Union] 1999) represent a primary wetland type that will deserve increased attention as a key global resource in the near future. This review is seen therefore as a necessary and overdue summary on riverine flood plains that complements reviews on other continental wetlands. Brinson and Malvaréz (2002) review the status of temperate wetlands and Junk (2002) treats subtropical and tropical wetlands in a more general way. Moore (2002) focuses on cool temperate bogs, while Malmqvist and Rundle (2002) review the state of rivers, and Williams (2002) summarizes the present and future state of inland saline water bodies.

The present review provides an overview on the actual extent of riverine flood plains, the major economic and ecological services they provide, and the multifaceted threats that make them to one of the most endangered landscapes worldwide. Further, we discuss their changing ecological status and finally we predict the conditions of flood plains 
in the year 2025 (see Foundation for Environmental Conservation 2001) under different scenarios of conservation/exploitation. Since flood plains, wetlands and freshwater systems are not always clearly distinguished in the published literature, general examples on fresh waters or wetlands are included in the present review if necessary.

\section{Definition and classification of flood plains}

Flood plains are defined as 'areas of low lying land that are subject to inundation by lateral overflow water from rivers or lakes with which they are associated' (Junk \& Welcomme 1990). This definition includes fringing flood plains of lakes and rivers, internal deltas and the deltaic flood plains of estuaries. Brinson (1990) and Brinson and Malvaréz (2002) proposed a hydrogeomorphic classification of wetlands that is based on the (1) geomorphic setting, (2) water source, and (3) hydrodynamics. Considering these components, riverine flood plains are located on low-gradient alluvial 'shelves'; water sources are primarily from lateral overspill of river water, although other sources may also contribute to floodplain inundation; and, although primarily unidirectional, water flow is characterized by highly complex, multidimensional exchange pathways. Four sources of water are recognized as contributing to floodplain inundation: lateral overflow, groundwater, upland sources and direct precipitation. Flood plains can be solely fed by rainfall such as the Flooding Pampa grasslands in Argentina (Perelmann et al. 2001); however, several sources normally contribute to inundation (Tockner et al. 2000a).

As riparian zones, flood plains are usually defined as ecotones between terrestrial and aquatic realms (Gregory et al. 1991; Malanson 1993) that extend from the low-water mark to the high-water line and also include the terrestrial vegetation influenced by elevated groundwater tables or extreme floods (Nilsson \& Berggren 2000; Naiman et al. 2000). In practice, there are several transition zones, and riverine flood plains may contain a complex of different wetland types.

Flood plains develop in all geographic regions and at different locations along river corridors (e.g. Tockner et al. $2000 a, b)$. For streams in the USA, the estimated average floodplain width ranges from $3 \mathrm{~m}$ for small rivers to about $1 \mathrm{~km}$ for the largest rivers (Table 1). Total floodplain area (all stream segments combined) is similar across different stream orders (Table 1). Riverine corridors are often composed of flood plains sequentially arrayed between canyons or bedrock constrained segments from the headwaters to the ocean. The floodplain segments can be as large as $90000 \mathrm{~km}^{2}$ as for the Nile River (Sudd, Sudan), although they range mostly from tens to hundreds of ha in small and medium-sized rivers (Stanford \& Ward 1993). Along large tropical rivers such as the Amazon, the Orinoco or the Magdalena, average floodplain widths are $32 \mathrm{~km}, 9 \mathrm{~km}$ and $35 \mathrm{~km}$, respectively (Hamilton \& Lewis 1990). The immense area that natural flood plains may cover is demonstrated by the Fly River
Table 1 Stream order, estimated number of streams, average and total length of rivers and streams, average riparian width and total floodplain surface area in the USA (modified from Leopold $e t$ al. 1964).

\begin{tabular}{lrrccl}
\hline \hline $\begin{array}{l}\text { Stream } \\
\text { order }\end{array}$ & Number & $\begin{array}{l}\text { Average } \\
\text { length } \\
(\mathrm{km})\end{array}$ & $\begin{array}{l}\text { Total } \\
\text { length } \\
(\mathrm{km})\end{array}$ & $\begin{array}{l}\text { Estimated } \\
\text { floodplain } \\
\text { midth }(\mathrm{m})\end{array}$ & $\begin{array}{l}\text { Floodplain } \\
\text { surface } \\
\text { area }\left(\mathrm{km}^{2}\right)\end{array}$ \\
\hline 1 & 1570000 & 1.6 & 2526130 & 3 & 7578 \\
2 & 350000 & 3.7 & 1295245 & 6 & 7771 \\
3 & 80000 & 8.5 & 682216 & 12 & 8187 \\
4 & 18000 & 19.3 & 347544 & 24 & 8341 \\
5 & 4200 & 45.1 & 189218 & 48 & 9082 \\
6 & 950 & 103.0 & 97827 & 96 & 9391 \\
7 & 200 & 236.5 & 47305 & 192 & 9082 \\
8 & 41 & 543.8 & 22298 & 384 & 8562 \\
9 & 8 & 1250.2 & 10002 & 768 & 7681 \\
10 & 1 & 2896.2 & 2896 & 1536 & 4449 \\
\hline \hline
\end{tabular}

(Papua New Guinea), one of the largest intact floodplain rivers in Australasia; $60 \%$ of the $76500 \mathrm{~km}^{2}$ catchment area becomes seasonally inundated, and the average floodplain width of the lower $800 \mathrm{~km}$ is more than $40 \mathrm{~km}$ (Swales et al. 1999).

\section{Flood plains are centres of biodiversity and bioproduction}

Flood plains are considered as centres of biocomplexity and bioproduction although this has never been rigorously tested in a regional landscape context (e.g. Megonigal et al. 1997). Indeed, more species of plants and animals by far occur on flood plains than in any other landscape unit in most regions of the world. In the Pacific coastal ecoregion (USA), for example, approximately $29 \%$ of wildlife species found in riparian forests are riparian obligates (ranging from 12\% of mammals to $60 \%$ of amphibians; Kelsey \& West 1998). Although $<1 \%$ of the landscape of the western USA supports riparian vegetation, this vegetation provides habitat for more species of breeding birds than any other vegetation association. For example, of all bird species breeding in northern Colorado, $82 \%$ occur in riparian vegetation, and about half of south-western species depend upon riparian vegetation (Knopf \& Samson 1994). Riparian areas in semiarid zones are also critical in providing stopover areas for en route migrants (acting as 'dispersal filters'), and therefore affect the breeding success of northern bird populations (Skagen et al. 1998). In tropical Asia, many nominally terrestrial mammals are associated with riverine wetlands for part of their life cycle, including important representatives of the 'charismatic megafauna' (e.g. Malayan tapir, Indian rhino; Dudgeon 2000a,b). However, the biodiversity associated with rivers and streams has been neglected in most areas of the world such as Asia or Africa. For example, the Mekong River contains 500 known fish species, although perhaps 1200 are expected (Dudgeon 2000a,b). A significant proportion of this 
diverse fish fauna depends on the rich resources provided by intact flood plains.

In Europe, 30\% of threatened bird species are inland wetland-dependent species and $69 \%$ of the important breeding areas for birds contain wetland habitats, primarily flood plains (Tiker \& Evans 1997). In Switzerland, 10\% of the entire fauna is restricted in its occurrence to riverine flood plains, although flood plains only cover $0.26 \%$ of the country's surface. Moreover, $28 \%$ of the fauna frequently uses flood plains and about $44 \%$ is occasionally found in flood plains (Table 2). In total, about $80 \%$ of the fauna occurs in riverine flood plains. A high proportion of the riparian obligates $(47 \%)$ is listed as endangered, compared to $28 \%$ for the entire fauna (Walter et al. 1998).

Flood plains are important centres of biological diversification. Fittkau and Reiss (1983) assumed that riverine flood plains belong to those aquatic ecosystems where biota of lentic areas (standing water bodies) started their evolution. The temporal continuity of riverine systems and their associated disturbance regime allowed the permanent presence of lentic and semi-lentic water bodies throughout time. The speciation of groundwater crustaceans is also supposed to be favoured by the lateral shifting of river channels that lead to the isolation of former connected channels (e.g. cyclopoid copepods in the alluvial aquifer of the Danube; P. Pospisil, personal communication 1996).

Flood plains are among the most productive landscapes on Earth, owing to continual enrichment by import and retention of nutrient-rich sediments from the headwaters and from lateral sources, and they are more productive than the parent river and adjacent uplands. Net primary production in

Table 2 Species pool of selected faunal groups in Switzerland and the number of species that are floodplain obligates $(\mathrm{K} 1)$, that are found frequently in flood plains $(\mathrm{K} 2+\mathrm{K} 3)$ and that occur occasionally in flood plains (K4), and the relative proportion (\%) of species within each category (K1-K4) in the total fauna (data from Walter et al. 1998; Tockner \& Ward 1999).

\begin{tabular}{lcccc}
\hline Group & $\begin{array}{l}\text { Total } \\
\text { number } \\
\text { of species }\end{array}$ & $\begin{array}{l}\text { Obligatory } \\
(\text { K1) }\end{array}$ & $\begin{array}{l}\text { Frequently } \\
(\text { K2-K3) }\end{array}$ & $\begin{array}{l}\text { Occasionally } \\
\text { (K4) }\end{array}$ \\
\hline Mollusca & 211 & 12 & 17 & 87 \\
$\quad$ terrestrial) & & & & \\
Odonata & 82 & 10 & 48 & 19 \\
Heteroptera & 750 & 47 & 170 & 530 \\
Saltatoria & 117 & 12 & 30 & 68 \\
Rhopalocera, & 204 & 6 & 29 & 120 \\
$\quad$ Hesperidae & & & & \\
Carabidae & 523 & 139 & 132 & 159 \\
Apoidea & 585 & 24 & 246 & 125 \\
Amphibia & 24 & 7 & 16 & 1 \\
Reptilia & 15 & 3 & 8 & 4 \\
Aves & 391 & 33 & 123 & 158 \\
Mammalia & 83 & 7 & 21 & 57 \\
Total & 2985 & $300(10 \%)$ & $840(28 \%)$ & $1328(44 \%)$ \\
\hline \hline
\end{tabular}

riparian forests ranges between 750 and $1370 \mathrm{~g} \mathrm{~m}^{2} \mathrm{yr}^{-1}$ (mean: c. $1000 \mathrm{~g} \mathrm{~m}^{2} \mathrm{yr}^{-1}$; Mitsch \& Gosselink 2000). The production of wetland/floodplain animals is probably $9.0 \mathrm{~g} \mathrm{~m}^{2} \mathrm{yr}^{-1}$, which is 3.5 times the value for terrestrial ecosystems (Turner 1982, cited in Keddy 2000). Production depends on hydrology. In Virginia flood plains (USA), aquatic invertebrate production ranges between 1.1 and $6.12 \mathrm{~g} \mathrm{~m}^{2} \mathrm{yr}^{-1}$, with highest values in the most dynamic segments (Gladden \& Smock 1990). Rivers derive nearly all their fish productivity from flood plains (e.g. Welcomme 1979; Bayley 1988). There is a positive correlation between fish catch and the maximum inundated floodplain area in African rivers, with fish yield being most influenced by the flood state in previous years (Welcomme 1975, 1979). The so called 'flood-pulse advantage' (sensu Bayley 1995) was recognized by the ancient Egyptians, since taxes were based on the extent of the annual flood of the Nile. On a worldwide basis, there is a quantitative relationship expressed as: fish catch $(\mathrm{kg})=5.46 \times$ floodplain area $(\mathrm{ha})$. Care has to be taken, however, as these studies are somehow conjecture since fish catch does not equate to fish production. Fish catch is usually adults, which may have achieved their production elsewhere, and not juveniles. Fish concentrate in flood plains and are often easier to catch there (Galat \& Zweimüller 2001).

\section{Economic importance of flood plains}

The estimated worldwide value of the services provided by flood plains is US\$3920 $\times 10^{9} \mathrm{yr}^{-1}$, assuming that total floodplain area is about $2 \times 10^{6} \mathrm{~km}^{2}$ and area-based value is US\$ $19580 \mathrm{ha} \mathrm{yr}^{-1}$ compared to US\$ $969 \mathrm{ha} \mathrm{yr}^{-1}$ for forests and US\$ $92 \mathrm{ha} \mathrm{yr}^{-1}$ for cropland (Constanza et al. 1997). In total, flood plains contribute $>25 \%$ of all terrestrial ecosystem services, although they cover only $1.4 \%$ of the land surface area (for discussion on floodplain area see Aselman \& Crutzen 1989; Mitsch \& Gosselink 2000). The major services of flood plains include disturbance regulation (37\% of their total value), water supply (39\%) and waste treatment (9\%). Value of floodplain land in Illinois (USA) was quantified as high as US\$ 7500 ha yr $^{-1}$, with $86 \%$ based on regional flood water storage (Schaeffer et al. 2002). Nitrogen removal, an important floodplain service, varies from 0.5 to $2.6 \mathrm{~kg} \mathrm{Nha}^{-1} \mathrm{day}^{-1} \quad$ (e.g. $2.6 \mathrm{~kg} \mathrm{NO}_{3}-\mathrm{N} \mathrm{ha}^{-1} \mathrm{day}^{-1}$ in a Danubian flood plain; Tockner et al. 1999). Flood plains along the Danube are valued at EUR $384 \mathrm{ha}^{-1} \mathrm{yr}^{-1}$ for recreation and nutrient removal (Andréasson-Gren \& Groth $1995 ; 1$ EUR $=0.88$ US $\$$, March 2001). Similarly, the nitrogen reduction capacity of Estonian coastal and floodplain wetlands is worth EUR $510 \mathrm{ha}^{-1} \mathrm{yr}^{-1}$. Barbier and Thompson (1998) valued the weighted aggregate of agricultural, fishing and fuelwood benefits of a Sahelian flood plain at US\$34-51 ha $\mathrm{hr}^{-1} \mathrm{yr}^{-1}$ The natural value of the flood plain would be even higher if other important benefits such as the role in pastoral grazing and recharging groundwater were included. Agricultural benefits of a planned irrigation project would, however, be only in the range of US\$20-31 ha $\mathrm{hr}^{-1}$. 
Firewood, recession agriculture, fishing, and pastoralism generate US $\$ 32$ per $1000 \mathrm{~m}^{3}$ flood water, compared to US\$ 0.15 per $1000 \mathrm{~m}^{3}$ water for irrigation. In the Inner Delta of the Niger River over 550000 people with about 1 million sheep and 1 million goats use the flood plain for post-flood dry season grazing (Dugan 1990). There are many other examples of how local communities make use of the diversity and productivity of flood plains and wetlands. Especially in drylands, the benefits of natural flood plains are very high and multifaceted.

Extensive development in flood plains has increased flood damages at unprecedented rates over the past years (e.g. Burby 2002). For example, there is a $26 \%$ chance of a property in the 100-year flood plain being damaged by flooding over the 30-year life of a standard mortgage (compared to $1 \%$ chance of fire damage; Burby 2002). In the USA, with 6 million buildings located within the boundaries of a 100-year flood plain, flood losses are widespread and losses from flood hazards have increased dramatically over the last decades (averaging US\$115 million per week) and will continue to do so in the next decades (Congressional Natural Hazard Caucus Work Group 2001).

\section{ENVIRONMENTAL FORCING FACTORS}

\section{Natural influences}

Flood plains are disturbance-dominated ecosystems characterized by a high level of habitat heterogeneity and diverse biota adapted to the high spatio-temporal heterogeneity. The formation and maintenance of flood plains is closely tied to fluvial dynamics (Hughes 1997; Ward et al. 1999a; cf. Fig. 1). Fluvial dynamics, including the expansion/contraction of surface waters ('flood and flow pulses'), is also the driving force that sustains connectivity in flood plains (Junk et al. 1989; Petts 1990; Tockner et al. 2000a; Ward et al. 2002; Table 3). Hydrologic connectivity, a key process in riverine flood plains, refers to water-mediated transfer of energy, matter and organisms within or among elements of riverine corridors. Inundation of flood plains is a complex phenomenon caused by different water sources via multiple pathways. Small changes in the relative contribution of individual water sources may drastically alter species composition and species diversity. For example, local groundwater upwelling is often associated with a higher standing crop of algae, higher zoobenthos biomass, faster growth rates of

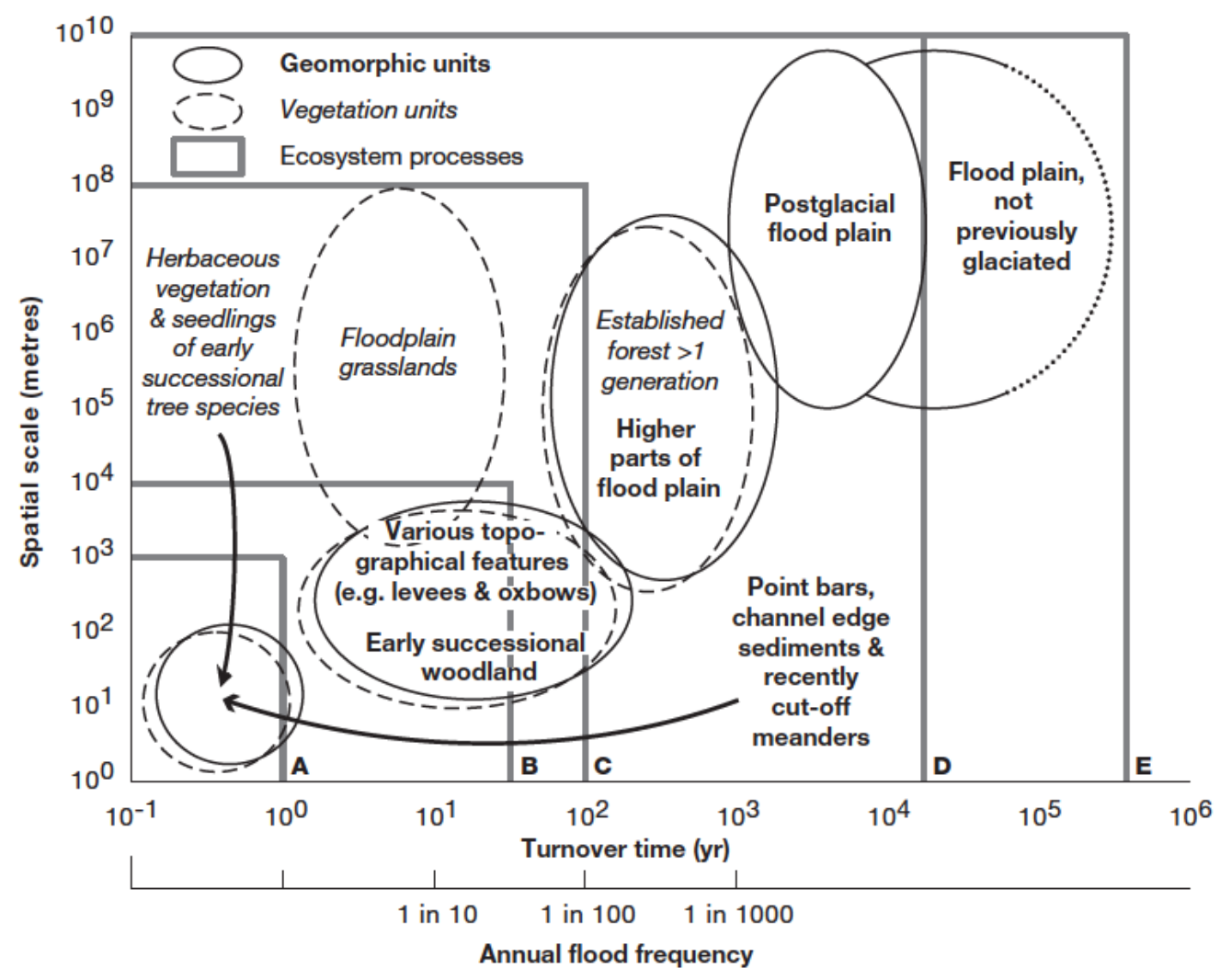

Figure 1 The organization of floodplain components and processes as a spatiotemporal hierarchy (after Hughes 1997). A = primary succession of herbaceous vegetation and early successional woody species, associated with annual flood; B = primary and secondary floodplain succession, associated with medium-magnitude/frequency floods; $\mathrm{C}=$ long-term floodplain succession, widespread erosion and reworking of sediment, associated with high magnitude/low-frequency floods; $\mathrm{D}=$ species migration upstream/downstream, local species extinction, long-term succession on terraces, and life-history strategies, associated with climate and base-level change, and the influence of postglacial relaxation phenomena on hydrological and sediment inputs to flood plains; and $\mathrm{E}=$ species evolution, and changes in biogeographical range, associated with tectonic change, eustatic uplift and climate change. 
Table 3 The estimated relative importance of environmental factors that determine the properties of wetlands in general (after Keddy 2000) and flood plains specifically (empirical values).

\begin{tabular}{lcc}
\hline Environmental factor & Wetland (\%) & Flood plain (\%) \\
\hline Hydrology & 50 & 60 \\
Fertility & 15 & $<10$ \\
Salinity & 15 & $<5$ \\
Disturbance & 15 & 30 \\
Competition & $<5$ & $<5$ \\
Grazing & $<5$ & $<5$ \\
Burial & $<5$ & $<5$ \\
\hline
\end{tabular}

cottonwood trees and a higher species richness of woody and herbaceous plants (J.A. Stanford, personal communication 2001). Despite its overwhelming importance in flood plains, hydrology is often given only cursory attention in restoration and mitigation projects (e.g. Bedford 1996).

\section{Human influences}

Flood plains are among the most altered landscapes worldwide and they continue to disappear at an alarming rate, since floodplain 'reclamation' (i.e. elimination) is much higher than for most other landscape types (Vitousek et al. 1997; Olson \& Dinerstein 1998; Ravenga et al. 2000). The net result is vast constriction of flood plains, sometimes by more than $50 \%$ of the historic expanse (Snyder et al. 2002). As a consequence, the decline of freshwater biodiversity, including the rich floodplain diversity, is much greater than in terrestrial systems. For example, $47 \%$ of all animals federally endangered in the USA are freshwater species (Stein 2001). Although no specific data are available, we may expect a disproportional contribution by floodplain species (see Table 2). The major factors responsible for the decline of freshwater biodiversity are habitat alteration, pollution, competition for water, invasive species and overharvest (Abramovitz 1996). Among these factors, land transformation is the single most important cause of species extinction (Vitousek et al. 1997). Habitat degradation and loss contribute to the endangerment of $85 \%$ of the imperiled species in the USA (Wilcove et al. 1998; Table 4). For freshwater groups, water development projects account for $91 \%$ of threats to endangered fish and $63 \%$ to endangered amphibians.

\section{Habitat alteration}

Habitat alteration includes both the degradation of the natural landscape and the modification of the hydrologic regime. Worldwide, more than $500000 \mathrm{~km}$ of waterways have been altered for navigation and more than $63000 \mathrm{~km}$ of canals have been constructed (e.g. Abramovitz 1996). In the USA, only $2 \%$ (about $100000 \mathrm{~km}$ ) of rivers have sufficiently high quality features to be worthy of federal protection status (Benke 1990). These free-flowing sections are often singlethread rivers that lack extensive flood plains. In Austrian
Table 4 Information on the relative importance (percentage) of different threats for 1880 (75\%) of the 2490 imperiled species in the USA, and for amphibians and fish separately. Categories are non-exclusive and therefore do not sum up to 100 (Wilcove et al. 1998).

\begin{tabular}{llll}
\hline Cause & $\begin{array}{l}\text { All species } \\
n=1880\end{array}$ & $\begin{array}{l}\text { Amphibians } \\
\boldsymbol{n}=\mathbf{6 0}\end{array}$ & $\begin{array}{l}\text { Fish } \\
\boldsymbol{n}=\mathbf{2 1 3}\end{array}$ \\
\hline Habitat degradation/loss & 85 & 87 & 94 \\
Alien species & 49 & 27 & 53 \\
Pollution & 24 & 45 & 66 \\
Overexploitation & 17 & 17 & 13 \\
Disease & 3 & 5 & 1 \\
\hline
\end{tabular}

rivers with catchment areas $>500 \mathrm{~km}^{2}$, it is the floodplain segments that have been most severely impacted. Today, less than $2 \%$ of former braided, anastomosing and meandering Austrian rivers are in a semi-pristine state, compared to $25 \%$ of single-thread headwater streams (Muhar et al. 1998).

To evaluate the effect of river regulation on selected Central European river-floodplain systems, we used shoreline length (the interface between the terrestrial and the aquatic compartments of the flood plain) as an index of habitat quality (Schiemer et al. 2001; K. Tockner, personal communication 2001). In dynamic systems (e.g. the Tagliamento River, Italy), shoreline length can be up to $25 \mathrm{~km}$ per river $\mathrm{km}$ and remains high throughout the annual cycle, except during major flood events. In channelized rivers, however, shoreline length drops to about $2 \mathrm{~km}$ per river km (Fig. 2). Reduction in shoreline length not only affects habitat availability of already endangered communities but also impedes the exchange of matter and organisms between the river and its riparian area (Naiman \& Decamps 1997).

Hydrology is by far the single most important driving variable in flood plains (see Table 3). Changes in river flow alter the extent, duration and frequency of floodplain inundation. After dam closure the Nile showed a reduced annual

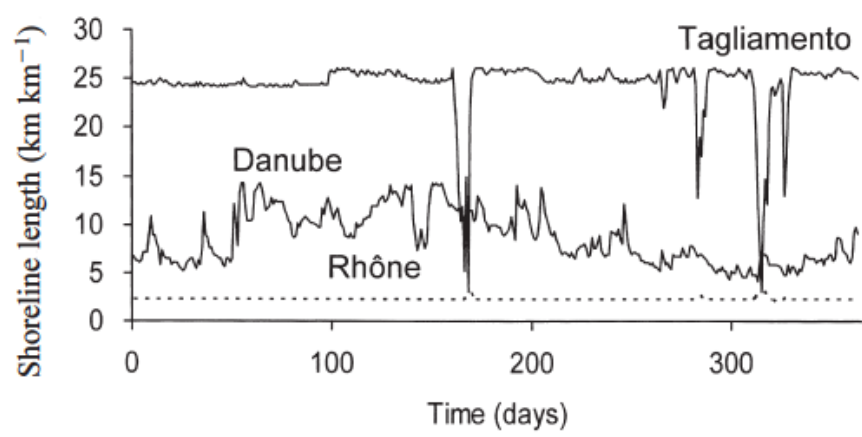

Figure 2 Shoreline length (km per river-km) in natural (Tagliamento, north-east Italy), constrained (Danube, Alluvial National Park, Austria) and channelized (Rhône, Switzerland) river-floodplain systems. All flood plains are characterized by a dynamic hydrology (Van der Nat et al. 2002; K. Tockner, personal communication 2001). The Rhône and the Tagliamento River are comparable in discharge and catchment area. In its pristine state, the Rhône was morphologically similar to the present Tagliamento. 
discharge, truncated annual floods, higher base flow rates and a several month shift in the timing of the flood peak. The maximum-to-minimum discharge ratio decreased from 12:1 to 2:1, with far-reaching consequences for floodplain inundation (Fig. 3). The Senegal River, however, showed a gradual decrease in peak, average, and low water discharge, primarily as a result of increasing water abstraction for irrigation (Fig. $3)$. During the dry season, the Senegal now frequently ceases to flow. The Danube River (downstream of Vienna, Austria) has a relatively unaltered hydrology with frequent 'flood' and 'flow' pulses (Fig. 3). However, the flood plain is disconnected from the main channel by artificial levees, which drastically reduce the duration and frequency of floodplain inundation (Tockner et al. 2000a,b; see also Fig. 2).

At present, about $3800 \mathrm{~km}^{3}$ of water is withdrawn annually worldwide, primarily for agriculture (Ravenga et al. 2000). Hydrological alterations by water withdrawal can be extreme in some systems; for example, less than $1 \%$ of the natural flow of the Colorado River reaches the mouth. The Murray River in Australia now discharges only $36 \%$ of its natural flow into the sea, flood duration on the fringing flood plains has decreased from two months to a matter of days, and the timing of floods has shifted from spring to late summer ( Jolly 1996).

At present, more than 40000 large dams ( $>15 \mathrm{~m}$ high) impound the world's rivers, inundating more than $400000 \mathrm{~km}^{2}$, increasing water storage capacity by $700 \%$, reducing sediment transport, and changing the chemistry of river inputs, with long-term consequences for coastal ecosystems (e.g. Ittekot et al. 2000). Countless smaller dams modify river dynamics locally (e.g. more than 2.5 million dams $<8 \mathrm{~m}$ high are estimated for the USA alone; Richter et al. 1997). In the USA, at least $90 \%$ of the total discharge of rivers is strongly altered hydrologically, mainly by damming and water abstraction (Jackson et al. 2001a).

Riverine systems are strongly threatened by changing land-use patterns in the whole catchment and especially along the riparian margin of rivers and streams. Based on data from 145 major catchments around the world (data from Ravenga et al. 1998), human impacts at both the catchment and the riparian level can be discerned (Fig. 4). Analysis of these data elucidates several patterns. Riparian areas are significantly more severely impacted than the total catchment (Wilcoxon matched pairs test, $p<0.0001, z=6.28$; Fig. $4 a$ ). The most impacted riparian corridors with respect to land use are found in Europe and in the densely populated areas in Asia (catchments with population densities $>200$ people per $\mathrm{km}^{2}$; Fig. $4 b$ ). There, between about $60 \%$ and $99 \%$ of the entire riparian corridor has been transformed to cropland and/or is urbanized, the latter in particular in Europe. The Seine River (France) shows the highest impact of all rivers investigated. There is a positive and linear relationship between human population density and land use of the riparian zone for Asian and African rivers $\left(y=0.28 x+10.41, r^{2}=0.73, p<0.0001\right.$; Fig. $4 b$ ). However, this relation is logarithmic rather than linear for European and American rivers $(y=15.4 \ln (x)+$ (a) Nile (Aswan)

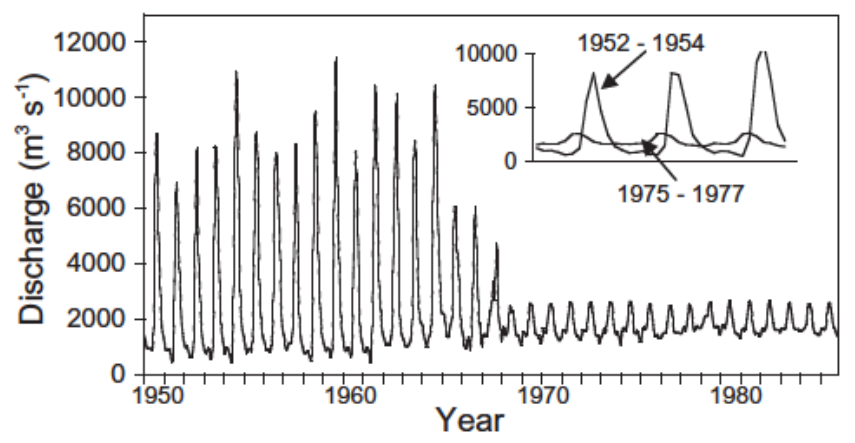

(b) Senegal (Bakel)

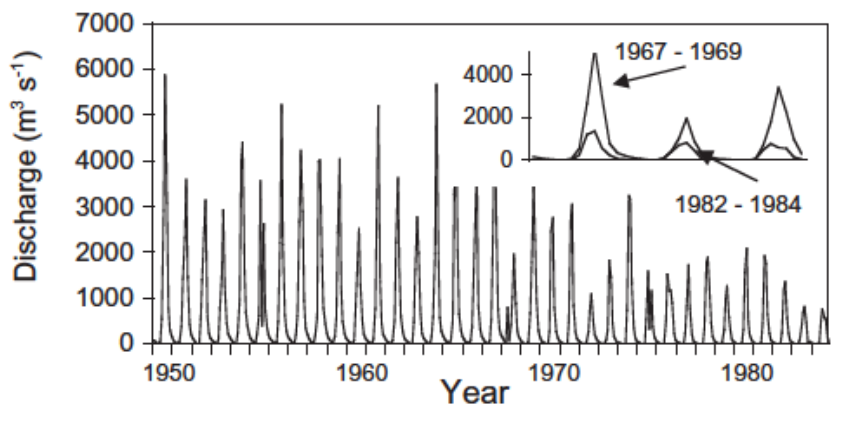

(c) Danube (Vienna)



Figure 3 Discharge patterns of selected rivers: (a) Nile River below the Aswan dam (UNESCO 1995), (b) Senegal River at Bakel (UNESCO 1995) and (c) Danube River downstream of Vienna (WSD Wasserstrassendirektion, Vienna, unpublished data, 1996).

$2.48, r^{2}=0.57, p<0.001$; Fig. $4 b$ ), where riparian zones are already highly 'developed' at a low level of population density (e.g. Mississippi, USA). The present analysis only considers areas with intensive agricultural development, mosaics of cropland and natural vegetation being excluded. Low landuse values for African and many Asian river corridors, therefore, can be explained by more traditional and sustainable use of their riparian area. Based on the data, $11 \%$ of the riparian area of African rivers (mean population density: 24 people per $\mathrm{km}^{2}$ ) is intensively cultivated compared to $46 \%$ for North American rivers (excluding northern Canada and Alaska; mean population density: 24 people per $\mathrm{km}^{2}$ ) and $79 \%$ for European rivers (mean population density: 75 people per $\mathrm{km}^{2}$ ). 
(a)

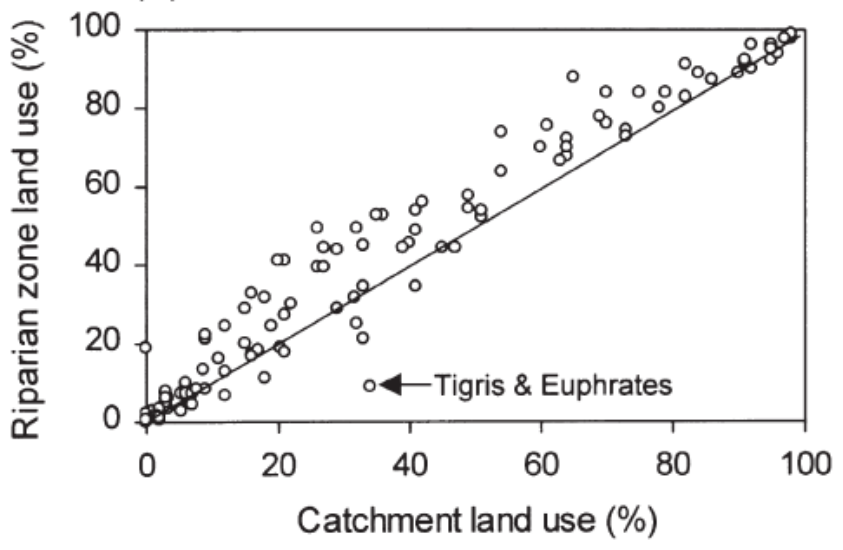

(b)

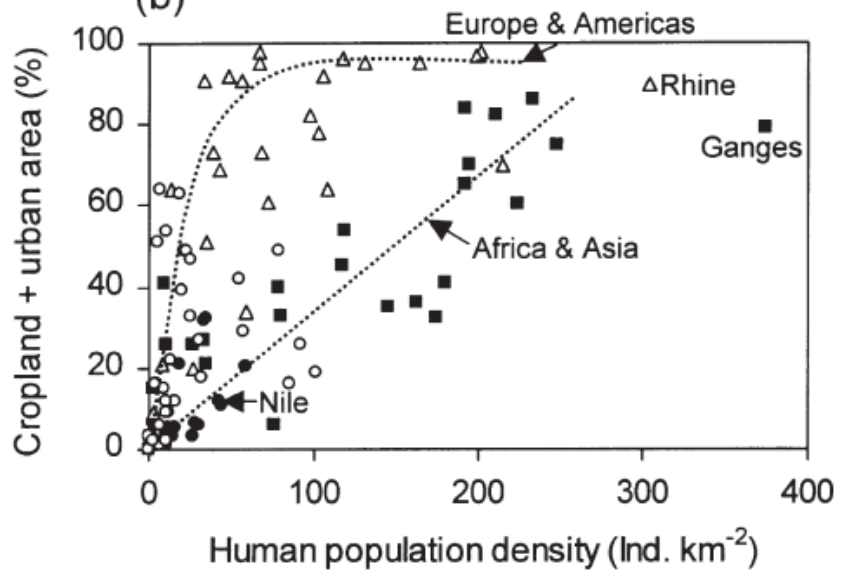

\section{- Africa - Asia $\triangle$ Europe 。Americas}

Figure 4 Land-use patterns in major catchments of the world. (a) Correlation between land-use in the total catchment and within the riparian corridor. ( $b$ ) Correlation between land-use and human population density (individuals per $\mathrm{km}^{2}$ ) in river catchments of different continents (data from Ravenga et al. 1998). Correlation between human population density and land use is indicated by broken lines for Africa/Asia and Europe/Americas. The areas of intensive agricultural land use and the urban areas were combined to calculate the relative proportion of intensively altered land for each of the 145 catchments and for riparian areas along the rivers. The riparian zone was defined as land within $5 \mathrm{~km}$ of major rivers within each catchment. The land-cover database was derived from $1 \mathrm{~km}$ resolution satellite data (April 1992-March 1993; Ravenga et al. 1998, 2000). The distribution of urban areas was based on satellite images of night-time lights for 1994-1995 (5 km resolution stable-light database, National Oceanic and Atmospheric Administration-National Geophysical Data Center 1998).

\section{Species invasion}

Species invasion is the second most important cause of the overall decline in aquatic biodiversity, leading to an accelerated rate of redistribution of the freshwater fauna. In riverine systems, the combination of land transformation, altered hydrology, and numerous deliberate and accidental species introductions has perpetuated widespread invasions. Many river systems are already dominated by alien species. Nonnative species comprise $79 \%$ of the fish fauna of the Colorado River, $38 \%$ of the fish of the Columbia River or $21 \%$ of the fish of the Rhine River (Galat \& Zweimueller 2001). The higher percentage of exotic plants and animals observed in flood plains compared to the uplands demonstrates the vulnerability of the riparian zone to invasion (Pysek \& Prach 1993). In fact, the same factors supporting high diversity in riparian habitats (transport of propagules, flooding disturbance, water availability) may also increase their susceptibility to invasion by exotic species (e.g. Pysek \& Prach 1993). Along the Adour River, France, 198 riparian plant species disappeared between 1989 and 1999, and, by 1999, there were 153 new species (Tabacchi \& PlantyTabacchi 2000). Today, invaders account for one-quarter of the total species richness of 1558 species and can locally constitute up to $40 \%$ of all species. Despite great differences in climate, species richness and land-use history, the proportion of invasive species along the Adour River is similar to rivers in the Pacific North-West of the USA and to South African Rivers (20-30\%; Hood \& Naiman 2000). In the southern USA, as a result of widespread human-induced changes in hydrology and land use, native cottonwoodwillow stands are being replaced by non-native woody species such as Russian olive (Eleagnus angustifolia) and tamarisk Tamarix sp. (saltcedar). Saltcedar now covers about $500000 \mathrm{ha}$ of flood plain in the western USA, its superior drought tolerance relative to native phreatophytes and its ability to produce high density stands and high leaf area indices being major reasons why it is favoured by in-stream flow reductions (e.g. Cleverly et al. 1997). Based on a costbenefit calculation, the presence of saltcedar in the Western USA will cost an estimated US $\$ 7-16$ billion in lost ecosystem function within the next decades (c. US\$ $15600-24600 \mathrm{ha}^{-1}$; Zavaleta 2000).

\section{Pollution}

Species composition and productivity of flood plains are influenced by the quality of the inflowing water. Artificially high nutrient inputs, for example, lead to an impoverishment of floodplain communities (e.g. lower Rhine; Van den Brink et al. 1996). Alternatively, the flood plain itself can serve as a major source of nutrients and pesticides when intensively cultivated; along many south-east Asian rivers huge amounts of pollutants are discharged into the main river during seasonal floods (e.g. Dudgeon 2000b).

In developing countries an estimated $90 \%$ of wastewater is discharged directly into rivers and streams without treatment, and in many parts of the world rivers are so polluted that their water is unfit even for industrial uses (Johnson $e t$ al. 2001). In China, $80 \%$ of the $50000 \mathrm{~km}$ of major rivers are too polluted to sustain fisheries and in $5 \%$ fish have been completely eliminated (FAO [Food and Agricultural Organization of the United Nations] 1999). Despite major treatment efforts, pollution is still a major problem in the 
Northern hemisphere (e.g. Van Dijk et al. 1994). For example, $75 \%$ of the water in the Vistula, Poland's largest river still containing many semi-natural flood plains, is unsuitable even for industrial use (Oleksyn \& Reich 1994). High nutrient concentrations of the parent river are also a major obstacle to restoring flood plains along many rivers such as the Danube or the Rhine (Buijse et al. 2002).

\section{PREDICTED LONG-TERM TRENDS}

Because rivers and wetlands are among the most threatened ecosystems worldwide (Vitousek et al. 1997; Ravenga et al. 2000), one of the major challenges is to meet increasing resource demands of a burgeoning human population while conserving aquatic ecosystems and the ecological services they provide for future decades. Many developing countries will experience a large increase in the relative water demand, in particular due to rapidly expanding cities (Vörösmarty $e t$ al. 2000; Johnson et al. 2001). Flood plains are particularly sensitive to changes in river hydrology, to increased alterations of the land-water interface, and to inputs of nutrients and toxicants (e.g. Naiman \& Décamps 1997; Ward et al. 1999a; Nilsson \& Berggren 2000; Ravenga et al. 2000).

\section{Changing water cycle}

Within the next decades, the sharp increase in human population combined with economic expansion will lead to greater pressures on freshwater resources, mainly through infrastructure development, water abstraction for agriculture and industry, conversion of land for resource development, and expansion in water withdrawal and consumption (e.g. Fig. 5). The effects of growing water consumption will be accentuated by land-use changes and by changes in the flow and flood

(a)



(b)

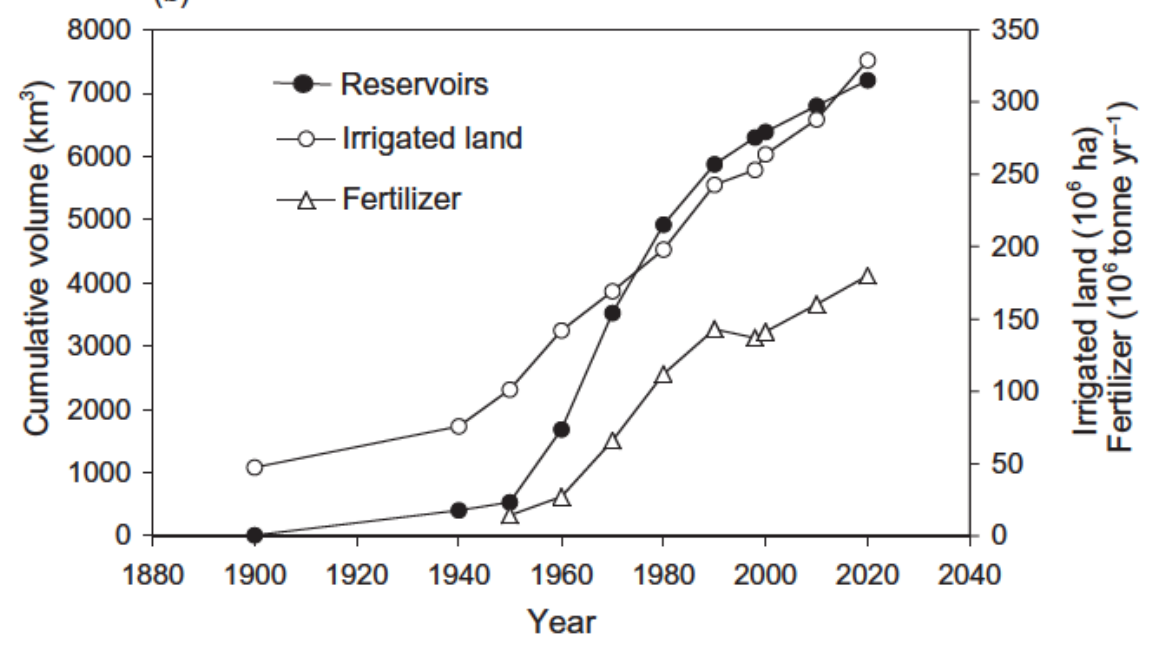

Figure 5 Global long-term trends with forecast to 2025 of (a) human population growth (UN 1998), water withdrawal and water consumption (Shiklomanov 1998) and (b) reservoir volume (Cosgrove \& Rijsberman 2000), irrigated land (Gleick 2000) and total use of fertilizers (Worldwatch Institute 2001). 
regime driven by climate change (IPCC [Intergovernmental Panel on Climate Change] 2001). This growing imbalance among freshwater supply, consumption and human population will cause a great intensification of the Earth's hydrological cycle (e.g. Jackson et al. 2001a). In the year 2025, $17-50 \%$ more water for irrigation will be needed. A rise of only $17 \%$ will be achieved only if water use efficiency is as high as $70 \%$, food consumption per person does not increase, and the relative contribution of irrigation to food production remains constant (Fig. 5). Most of the increase in irrigation will occur in the developing countries, particularly in southeast Asia and Africa (Serageldin 1999). In Europe, future quantitative pressures on natural water resources might tend to stabilize in the central and northern countries, but will increase greatly in the southern and eastern countries. Increases of up to $100 \%$ by 2025 have been predicted for many Mediterranean countries making the remaining wetlands and flood plains particularly vulnerable (Margat \& Vallee 1999).

About 300 large dams $(>15 \mathrm{~m})$ are currently built every year, in particular in developing countries (Fig. 5). New dams, despite major concern about expected environmental and socio-economic impacts will threaten most of the present large free-flowing rivers. In the Brazilian Amazon alone, a total of 79 major hydrologic dams $(100-13000 \mathrm{MW})$ are planned. As many as 278 dams could be constructed in the La Plata basin in Argentina and 32 dams are either planned or have been built in the Magdalena basin, Colombia (Pringle 2001). Along the mainstem Mekong River, 12 sites for dams have been identified that will completely alter the ecosystem (Dudgeon 2000c). The Three-Gorges dam along the Yangtze River will probably not be able to prevent future damage by floods, a major rationale for its construction. The hydraulic retention capacity of the impounded reservoir only compensates for the natural retention capacity of floodplain lakes lost during the last decades (e.g. the Dongtin floodplain lake alone lost about $40 \%$ of its immense volume between 1954 and 1983; Zong \& Chen 2000).

Projected changes during the 21st century caused by climate change include more intensive precipitation events over many areas (very likely), increased summer drying over most mid-latitude continental interiors and associated risks of drought (likely) and higher minimum temperatures (very likely; IPCC 2001). Changes in climate could increase the risk of abrupt and non-linear changes in many ecosystems, which would affect their function, biodiversity and productivity. A warming of $3-4^{\circ} \mathrm{C}$ is predicted to eliminate $85 \%$ of all remaining wetlands (UNEP-WCMC [United Nations Environment Programme-World Conservation Monitoring Centre] 2001). The flow regime of the River Rhine, for example, will change from a combined rain-fed/snow-fed to a predominantly rain-fed regime, associated with an increase in interannual variation and larger floods (Middelkoop \& Kwadijk 2001). Projected effects for flood plains include low water during the growing season and higher water temperatures. The return period of extreme precipitation events will decrease almost everywhere. In 2070, for example, floods that presently have 20-year return periods are projected to occur twice as often (Zwiers \& Kharin 1998). For North Carolina, USA, an increase in precipitation of $15 \%(5-30 \%)$ is predicted by 2100 , which will shift floodplain boundaries and make recent human developments in floodplain areas especially vulnerable to flood damage. Similar effects are predicted for the Pacific North-West.

\section{Changing floodplain area}

Accurate global assessments of wetland extent are elusive due to their complexity and highly dynamic nature (Finlayson \& Davidson 1999), but, based on recent estimates, wetlands cover nearly $10 \%$ of the Earth land surface; of these $2 \%$ are lakes, $30 \%$ are bogs, $26 \%$ are fens, $20 \%$ are swamps and $15 \%$ are flood plains (Ramsar \& IUCN 1999). Estimates of floodplain area vary as a function of the criteria used to delineate them. The area of a flood plain can be delineated by hydrologic (area inundated by a 100-year flood), geomorphic (area covered by recent alluvial deposits) or ecological criteria (area colonized by organisms adapted to flooding).

In the following, we provide an overview of global floodplain distribution patterns and discuss their present and future state. This is a difficult task since many estimates of floodplain size are based on old references, and there are major inconsistencies between different sources (see Table 6 later). An added difficulty is that adequate information on the extent and status of flood plains is not available for large geographic regions, such as the central and eastern parts of the former USSR. Flooding along the Lena River in the year 2000 , as a result of extensive ice-jams, has shown that vast areas of lowland Siberia are composed of fringing flood plains. At a global scale, total floodplain area estimates vary from $0.8 \times 10^{6} \mathrm{~km}^{2}$ (Aselmann \& Crutzen 1989) to $1.65 \times$ $10^{6} \mathrm{~km}^{2}$ (flood plains and swamps; Constanza et al. 1997) to $2.2 \times 10^{6} \mathrm{~km}^{2}$ (flood plains along rivers and lakes; Ramsar \& IUCN 1999).

Flood plains vary markedly in size. The largest gap and uncertainty in floodplain characterization is the size and duration of floodplain inundation. Sahagian and Melack (1998) suggested that floodplain extent should be expressed in terms of hectare-days (or equivalent units), thereby allowing both spatial and temporal analysis of key ecological and biogeochemical functions. In Table 5, we list expansion and contraction patterns of selected flood plains. The large geographic differences in the timing and the extent of flooding are further complicated by human impacts such as water abstraction and regulation. Along the lower Mississippi, for example, the ratio of high water (HW):low water (LW) area decreased from about 17 before regulation to $<5$ at present (Table 5). Decline in inundation area is often associated with a shift in inundation timing (e.g. Nile River; Fig. 3). Most flood plains experience large seasonal and interannual fluctuations. Flood plains in the Mediterranean as well as in other dry areas are particularly sensitive to 
Table 5 Inundated floodplain area $\left(\mathrm{km}^{2}\right)$ at low water $(\mathrm{LW})$ and high water $(\mathrm{HW})$, the timing of flooding and the ratio of $\mathrm{HW}$ :LW areas for selected temperate and tropical floodplain rivers. ${ }^{1}$ Floodplain segment; flooding may occur at any time of the year; ${ }^{2}$ channel network length $(\mathrm{km}) ;{ }^{3}$ frequently, there are also winter floods; and ${ }^{4}$ seasonal flood regime has been greatly modified during recent decades.

\begin{tabular}{|c|c|c|c|c|c|}
\hline Flood plain & Low pater $(L W)$ & High water $(H W)$ & Timing of flood & $H W: L W$ & Reference \\
\hline \multicolumn{6}{|l|}{ Europe } \\
\hline Tagliamento (Italy) ${ }^{1}$ & 0.10 & 1.43 & Oct-Nov & 14.3 & Van der Nat et al. (2002) \\
\hline Danube (Austria) ${ }^{1}$ & 0.52 & 5.2 & Apr-June & 10 & Tockner et al. (2000b) \\
\hline Val Roseg (Switzerland) $)^{2}$ & 5.8 & 21.2 & June-Sept & 3.7 & Tockner et al. (1997) \\
\hline Lower Rhine (The Netherlands) ${ }^{3}$ & 118.1 & 384.3 & Apr-June & 3.3 & $\begin{array}{l}\text { T. Buijse (personal } \\
\quad \text { communication 2001) }\end{array}$ \\
\hline \multicolumn{6}{|l|}{ Americas } \\
\hline Ogeechee & 0.10 & 7.46 & Feb-Apr & 75 & Benke et al. (2000) \\
\hline \multicolumn{6}{|l|}{ Lower Mississippi } \\
\hline (before regulation) & 2550 & 42825 & Mar-June & 16.8 & Baker et al. (1991) \\
\hline Lower Mississippi (present) ${ }^{4}$ & 1620 & 7970 & Mar-June & 4.9 & Baker et al. (1991) \\
\hline Orinoco: fringing flood plain & 400 & 7000 & July-Sept & 17.5 & Hamilton and Lewis (1990) \\
\hline Amazon (Brazil, mainstem) & 19000 & 91000 & May-July & 4.8 & Sippel et al. (1998) \\
\hline \multicolumn{6}{|l|}{ Africa } \\
\hline Hadejia-Nguru (Nigeria) & 4.9 & 2350 & July-Oct & 480 & Hollis et al. (1993) \\
\hline $\begin{array}{l}\text { Senegal flood plain } \\
\quad \text { (Senegal, Mauretania) }\end{array}$ & 500 & 4560 & Aug-Sept & 9.1 & $\begin{array}{l}\text { Howard-Williams and } \\
\text { Thompson (1985) }\end{array}$ \\
\hline Sudd (Sudan) & 10000 & 92000 & Aug-Sept & 9.2 & Rzóska (1974) \\
\hline Barotse plain (Zambia) & 330 & 5120 & Mar-Apr & 15.6 & Welcomme (1975) \\
\hline Pongolo River (South Africa) & 26 & 100 & Jan-Feb & 3.8 & Heeg \& Bren (1982) \\
\hline Kafue flat (Zambia) & 13000 & 28000 & Feb-Apr & 2.2 & Thompson (1996) \\
\hline \multicolumn{6}{|l|}{ Chari \& Lagone rivers } \\
\hline (Chad system) & 6300 & 63000 & July-Dec & 10 & Thompson (1996) \\
\hline
\end{tabular}

Table 6 Distribution and extent of selected fringing riverine flood plains (including a few rain-fed flood plains). Area of flood plain is

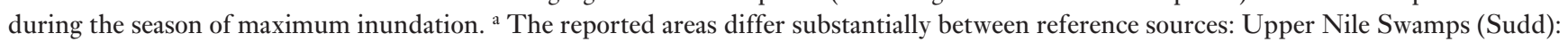
$>30000 \mathrm{~km}^{2}$ (Mitsch \& Gosselink 2000), $50000 \mathrm{~km}^{2}$ (Groombridge 1992) and > $90000 \mathrm{~km}^{2}$ (Howard-Williams \& Thompson 1985). Central Niger Delta: $30000 \mathrm{~km}^{2}$ (Howard-Williams \& Thompson 1985) and $320000 \mathrm{~km}^{2}$ (Mitsch \& Gosselink 2000). Middle Congo depression: $70000 \mathrm{~km}^{2}$ (Howard-Williams \& Thompson 1985) and $200000 \mathrm{~km}^{2}$ (Mitsch \& Gosselink 2000). Several major 'flood plains' listed are composed of different wetland types including swamps, wet grasslands or shallow lakes (e.g. Kagera valley, Central Congo basin, Sudd, Orinoco delta). ${ }^{\mathrm{b}}$ Data compiled by Howard-Williams and Thompson (1985) and Thompson (1996). Flood plains in Mozambique or Angola are not included since not enough information was available at the date of compilation (Howard-Williams \& Thompson 1985; Thompson 1996). ${ }^{\mathrm{c}}$ Dadnadji and Van Wetten (1993) report that wetlands along the Lagone and Chari cover $78000 \mathrm{~km}^{2}$ including inundated flats, riverine floodplains, marshes and smaller lakes. ${ }^{\mathrm{d}}$ Plantations cover $50 \%$ of the remaining flood plains.

\begin{tabular}{lcl}
\hline \hline Drainage system/geographic area & Area $\left(\mathrm{km}^{2}\right)^{a}$ & Major flood plains/reference \\
\hline Africa & & \\
Zaire/Congo system & 70000 & Middle Congo depression, Kamulondo, Malagarasi \\
Niger/Benue system & 38900 & Niger central delta, Benue River \\
Nile system & 93000 & Sudd, Kagera basin \\
Zambesi system & 19000 & Kafue flats, Barotse plain, Liuwa plain \\
Western systems & 19000 & Flood plains along the Senegal (excluding delta), Volta and Ouémé \\
South-east systems & 100 & Pongolo flood plain \\
Eastern systems & 8600 & Kilombero, Rufiji, Tana River \\
Chad system & & Chari \& Lagone River system \\
Gash River & 3000 & Inner Delta in Sudan (primarily woodland and savannah; Kirkby \& \\
& 3000 & O'Keefe 1998) \\
Tana Delta & 670 & Endangered by upstream dams \\
Europe & & \\
Switzerland & 110 & In total, 169 flood plains of national importance (BUWAL 1993) \\
The Netherlands & 498 & Area regularly flooded by rivers (primarily meadows; Yon \& Tendron 1981) \\
Danube National Park (Austria) & 93 & The last remaining semi-natural flood plain along the Upper Danube \\
& & (Tockner et al. 2000a)
\end{tabular}




\begin{tabular}{|c|c|c|}
\hline Drainage system/geographic area & $\operatorname{Area}\left(\mathrm{km}^{2}\right)^{a}$ & Major flood plains/reference \\
\hline Kopacki rit (Croatia) & 177 & $\begin{array}{l}\text { Semi-natural flood plain at the intersection of the Danube and the Drava } \\
\text { (Spanjol et al. 1999) }\end{array}$ \\
\hline Upper Rhine & $70^{\mathrm{d}}$ & Originally, flood plains covered $1000 \mathrm{~km}^{2}$ (Carbiener \& Schnitzler 1990) \\
\hline French Rhône (fringing flood plain) & 70 & $\begin{array}{l}\text { Mostly functionally extinct flood plains. Former extent: } 830 \mathrm{~km}^{2} \text { (Bravard } \\
\text { 1987) }\end{array}$ \\
\hline Rhône (delta, Carmargue) & 750 & Former delta: $1644 \mathrm{~km}^{2}$ (Bravard 1987) \\
\hline Guadiana River (Spain) & 450 & $\begin{array}{l}\text { Floodplain marshes in the Donana National and Nature Parks (Benayas et al. } \\
\text { 1999) }\end{array}$ \\
\hline Danube delta & 5800 & $\begin{array}{l}\text { Danube Delta Biosphere Reserve, c. } 50 \% \text { this area belongs to the 'Danube } \\
\text { Delta' (Riza 2000) }\end{array}$ \\
\hline Danube islands (Bulgaria) & 107 & $\begin{array}{l}75 \text { islands in the main stem (Bulgarian Ministry of Agriculture and Forests } \\
\text { 2001) }\end{array}$ \\
\hline Dnieper River delta (Ukraine) & $c .500$ & $\begin{array}{l}\text { Hydrologic impact by unpredictable flood releases from upstream dams, } \\
\text { pollution (Timchenko et al. 2000) }\end{array}$ \\
\hline Volga delta & 18000 & Largest European delta (Czaya 1981) \\
\hline Tisza (Hungary, Ukraine, Romania) & 1800 & Remaining area represents only $4.7 \%$ of former flood plains (Haraszthy 2001) \\
\hline Poland & 820 & Originally, flood plain forests covered $27800 \mathrm{~km}^{2}$ (Sienkiewicz et al. 2001) \\
\hline European part of Russia & 9000 & Approximate estimation (Shatalov 2001) \\
\hline \multicolumn{3}{|l|}{ North America } \\
\hline Ogeechee & 150 & Subtropical river in south-east USA (Benke et al. 2000) \\
\hline Kissimmee (Lower basin) & 180 & Disconnected at present, will be partly restored (e.g. Warne et al. 2000) \\
\hline Altamaha and Tone Rivers & 400 & Mertes (2000) \\
\hline Upper Mackenzie river & 60000 & A complex of marshes, fens and flood plains (Fremlin 1974) \\
\hline Mackenzie delta & 13000 & Including 24000 lakes (Marsh et al. 1999) \\
\hline Lower Missouri River flood plain & 7700 & At present mainly agricultural land (D. Galat, personal communication 2001) \\
\hline Mississippi River flood plain & 20000 & $\begin{array}{l}\text { Remaining bottomland hardwood forests out of formerly } 85000 \mathrm{~km}^{2} \\
\text { (Llewellyn et al. 1996) }\end{array}$ \\
\hline Rocky Mountain states (USA) & c. 4000 & Abernethy and Turner (1987) \\
\hline Washington and Oregon & 12500 & Abernethy and Turner (1987) \\
\hline Alaska & 120000 & c. $50 \%$ of present floodplain area in USA (Mitsch \& Gosselink 2000) \\
\hline \multicolumn{3}{|l|}{ South America } \\
\hline Amazon River & 890000 & $\begin{array}{l}\text { Large and small river flood plains combined (Aselman \& Crutzen 1989; } \\
\quad \text { Sippel et al. 1998) }\end{array}$ \\
\hline Orinoco delta & 30000 & Complex of flood plains, marshes and swamps (Groombridge 1992) \\
\hline Orinoco fringing flood plain & 7000 & Hamilton and Lewis (1990) \\
\hline Pantanal & 130000 & The 'largest' single wetland complex on earth (Hamilton et al. 1996) \\
\hline Parana & 20000 & Fringing flood plains (Welcomme 1979) \\
\hline Magdalena & 20000 & Deltic flood plain (Welcomme 1979) \\
\hline Flooding Pampa grassland (Argentina) & 90000 & $\begin{array}{l}80 \% \text { of the area still covered by natural grasslands, fed by rain (Perelman } \\
\text { et al. 2001) }\end{array}$ \\
\hline \multicolumn{3}{|r|}{ 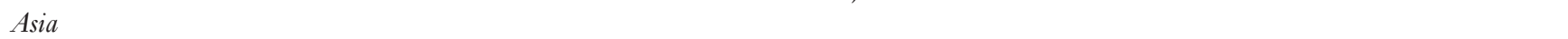 } \\
\hline China & 80000 & $\begin{array}{l}\text { Riverine and partly lacustrine wetlands in the Yangtze and Yellow-Huaihe } \\
\text { Basin (Lu 1995) }\end{array}$ \\
\hline Lena and Yana deltas & 38700 & Largest northern delta complex \\
\hline Mekong (Kampuchea) & 11000 & $\begin{array}{l}\text { Inundated forests along the Mekong and the shores of Le Grand Lac } \\
\text { (Pantulu 1986) }\end{array}$ \\
\hline Irrawady (Burma) & 31000 & Welcomme (1979) \\
\hline Indonesia & 119500 & Primarily in Kalimantan and Irian Jaya (Lehmusluoto et al. 1999) \\
\hline Bangladesh & 98000 & Primarily cultivated, including $28000 \mathrm{~km}^{2}$ of rice fields (Welcomme 1979). \\
\hline Ganges and Brahmaputra (India) & 23000 & Flood prone area, heavily cultivated (FAO 2001) \\
\hline Yellow River (China) & 120000 & $\begin{array}{l}\text { Including parts of the Hai and Huai Rivers (DHI Water \& Environment } \\
\text { 2001) }\end{array}$ \\
\hline Tigris and Euphrates & 20000 & $\begin{array}{l}\text { Mesopotanic region; cultivated flood plain (Al Hamed 1966); about } 7600 \mathrm{~km}^{2} \\
\text { has disappeared since } 1973 \text { (UNEP 2001) }\end{array}$ \\
\hline \multicolumn{3}{|r|}{ - } \\
\hline Fly River (Papua New Guinea) & 45000 & Swales et al. (1999) \\
\hline Kakadu National Park (Australia) & 260 & $13 \%$ of the park area (Gill et al. 2000) \\
\hline Chowilla anabranch (Australia) & 200 & $\begin{array}{l}\text { Largest remaining natural floodplain forest along the lower Murray River } \\
\text { (Jolly 1996) }\end{array}$ \\
\hline Cooper Creek and Paroo River (Australia) & 106000 & Endorheic flood plains in Central Australia (Kingsford et al. 1998) \\
\hline
\end{tabular}


hydrologic alterations, and they will experience a major future reduction in the $\mathrm{HW}: \mathrm{LW}$ ratio.

In Africa, by far the most extensive wetlands are seasonally-flooded savannah and forested flood plains, which comprise nearly half of the total wetland area of that continent. Howard-Williams and Thompson (1985) listed 44 large African flood plains or wetlands that have major floodplain elements. Nineteen of these floodplain complexes cover a total area of $307000 \mathrm{~km}^{2}$ (Thompson 1996). This is probably a great underestimation since large areas like the Central Congo basin (at least $100000 \mathrm{~km}^{2}$ ) or flood plains along the rivers in Mozambique and Angola as well as the countless smaller flood plains are not included. Many of the large African flood plains are still relatively untouched, however they are disappearing or are being transformed at an accelerating rate as a result of water management activities, in particular by large-scale irrigation schemes and the ongoing construction of dams (Fig. 3). For example, the inundated area of the Hadejia-Nguru flood plain in northern Nigeria decreased within the last decade from $2350 \mathrm{~km}^{2}$ to between 700 and $1000 \mathrm{~km}^{2}$ as a result of altered hydrology (Barbier \& Thompson 1998). The floodplain forests of the Tana River (Kenya) are drying up mainly because of the truncation of floods by the construction of upstream dams (e.g. Hughes 1988). In many Sahelian flood plains, water depth is very shallow during inundation, making them extremely sensitive to even minor hydrological changes (e.g. Senegal River; Fig; $3)$. For example, the flood plain of the Sudd (Sudan) is covered on average by water of about $1 \mathrm{~m}$ depth, although the area inundated can be up to $90000 \mathrm{~km}^{2}$. Along the Nile, the construction of the Aswan High Dam completely changed the seasonal flood dynamics. Effects persist for more than $1000 \mathrm{~km}$ downstream, with further impacts on the fisheries of the Eastern Mediterranean, erosion of the deltic area and salt intrusion upstream (Abu Zeid 1989).

North America has lost about $50 \%$ of its original wetland cover. The largest decline of any wetland category was for forested freshwater wetlands, primarily riverine flood plains. Originally, flood plains covered $7 \%$, or about $700000 \mathrm{~km}^{2}$, of all land in the USA (Kusler \& Larson 1993). Nowadays, pristine flood plains are primarily limited to Alaska, where about $50 \%$ of the extant flood plains occur. Along the Missouri River in the state of Missouri, between 1879 and 1972 channel length was shortened by $73 \mathrm{~km}$, aquatic surface area decreased by $50 \%, 97 \%$ of islands and $63 \%$ of the riparian forest disappeared, cultivated land increased by $65 \%$ and commercial fishery yield dropped by $85 \%$ (Galat et al. 1998). Along the Mississippi $90 \%$ of the flood plain (former area: $123000 \mathrm{~km}^{2}$; Sparks et al. 1998) is leveed. During the 1993 flood, however, about $70 \%$ of the $2530 \mathrm{~km}$ long artificial levees were damaged (Myers \& White 1993). Remaining floodplain forests on the Mississippi alluvial plain downstream of the Ohio River confluence cover $18700 \mathrm{~km}^{2}$, corresponding to a loss of about $80 \%$ of the original cover (Llewellyn et al. 1996). During the great flood in 1927, however, flood waters of the Mississippi inundated about
$52000 \mathrm{~km}^{2}$ downstream of Cairo, Illinois, USA. Along the Upper Mississippi, $10380 \mathrm{~km}^{2}$ of flood plain are still unleveed and retain seasonal flood pulses, one of the few such situations in the developed world.

About $20 \%$ of the South American tropical lowlands are regularly flooded (Junk 1997, 2002). In the upper Amazon basin, $26 \%$ of the present-day lowland forests have the characteristics of recent erosional and depositional dynamics, and $12 \%$ are in successional stages along the active river channels (Salo et al. 1986). Along the Peruvian lowland Amazon (including local tributaries) about $100000 \mathrm{~km}^{2}$ are classified as flood plains (Krist \& Nebel 2001).

In Siberia, the Lena River forms the largest northern delta and contains up to 150 separate river branches. In China, more than $600000 \mathrm{~km}^{2}$ are covered by wetlands, although about $60 \%$ are artificial (mainly paddy fields; Lu 1995). In 1953 and 1998, the Yangtze River (China) flooded areas of $475500 \mathrm{~km}^{2}$ and $212000 \mathrm{~km}^{2}$, respectively, killing thousands of people and causing immense economic damage (Zong \& Chen 2000). In Bangladesh, the landscape itself has an average age of less than 10000 years, and the entire nation has essentially been created on a giant flood plain, the world's largest delta (Khalil 1990). More than $20 \%$ of the country is regularly flooded $\left(23000 \mathrm{~km}^{2}\right)$, with up to $70 \%$ inundation during an extreme flood event (e.g. in 1988). However, most of this giant flood plain has been transformed into productive agricultural land supporting one of the world's most densely populated regions. The use of climate change models predicts substantial increases in mean peak discharges within the next decades (Mirza 2002). Asian flood plains are likely to experience the greatest change within the near future (Dudgeon 2002). The main threats will be: deforestation and drainage-basin alterations that destroy in-stream and riparian habitats; river regulation including flow modification; pollution; and overharvesting (mainly fish and reptiles). The damming of the Tigris and Euphrates led to a dramatic drying of large parts of the Mesopotanian flood plains, one of the world's most significant wetland complexes and a biodiversity centre of international importance, with several endemic species now at risk of extinction. During the last decades more than $9000 \mathrm{~km}^{2}$ of Mesopotanian wetlands disappeared (UNEP 2001).

In Australia, the combined area of flood plains along the Murray River is about $1000 \mathrm{~km}^{2}$, with most of the individual flood plains being $<10$ ha in size (Mackey \& Eastburn 1990). Along Cooper Creek and the Paoo River in Central Australia, one of the world's largest endorheic drainage systems (catchment: $1.14 \times 10^{6} \mathrm{~km}^{2}$ ), up to $106000 \mathrm{~km}^{2}$ become flooded (Kingsford et al. 1998). During major floods, water spreads over a maximum width of $60 \mathrm{~km}$. In arid Australia climate change will result in a drying or reduced frequency of large flood events with catastrophic effects for many biota, particularly water birds, which use a mosaic of wetland habitats at broad spatial scales (Roshier et al. 2002).

European flood plains are presently in a critical situation (e.g. Wenger et al. 1990; Klimo \& Hager 2001). European 
wetlands (excluding the European part of Russia) cover $404000 \mathrm{~km}^{2}$, about $4.4 \%$ of the land surface (WWF [World Wide Fund for Nature] \& EU [European Union] 2001). This is a rough estimate since an adequate database is available for only six out of 44 countries. Overall, about $50 \%$ of the original wetlands are lost; however, the rate is much higher for riverine flood plains with a loss of up to $95 \%$ (Table 6). In Hungary, for example, as recently as the end of the 19th century, the lowland river Tisza, the largest Danube tributary, transformed half of the Great Hungarian Plain into a giant flooded lake almost every year at the time of the melting snows (Fig. 6). Lateral damming has reduced the flood plain by $>90 \%$. However, during recent years, severe floods again inundated the entire former flood plain causing major damage. Switzerland has lost about $95 \%$ of its original flood plains during the last two centuries. The remaining areas, which are included in the inventory of 'flood plains of national importance', are heavily influenced by water abstraction, gravel mining, and fragmentation (BUWAL [Bundesamt für Umwelt, Wald und Landschaft] 1993). Eighty per cent of the flood plains of national importance are decoupled from the hydromorphological dynamics of the river. Today, the largest remaining floodplain fragment in Switzerland covers an area of only $3 \mathrm{~km}^{2}$.

Many of the remaining European flood plains are far from pristine and have lost most of their natural functions. For example, of the former $26000 \mathrm{~km}^{2}$ floodplain area along the Danube and its major tributaries, about $20000 \mathrm{~km}^{2}$ were separated by levees and have therefore become 'functionally' extinct, which means that the basic attributes that sustain the flood plain such as regular flooding or morphological dynamics are missing (Busnita 1967; Nachtnebel 2000). The fringing flood plains along the Austrian Danube between Vienna and Bratislava have been designated as an internationally recognized national park, despite major morphological and hydrological modifications and heavy nutrient loads of the parent river (Tockner et al. 2000b). Although greatly impacted, these floodplain segments deserve protection since they are the most valuable areas remaining along the entire corridor. These flood plains show still a high degree of reversibility making them suitable focal points for restoration (e.g. Schiemer et al. 1999).

Because $>90 \%$ of European flood plains are already 'cultivated', even impacted systems that retain some semblance of natural functions, such as flood plains along the Oder River (Poland/Germany), the Danube River, or along eastern European river corridors, are worthy of protection.

Wetlands and flood plains are inhabited by a variety of 'endemic' human societies that are well adapted to wetland conditions and that have developed a rich local culture. Many of these people are already listed as threatened by the Society of Threatened Peoples (http://www.gfbv.de), and there is a great risk that the ongoing environmental impact on large river-floodplain complexes will also increase the future risk of their extinction. Examples include the Lozi people in the Borotse flood plain, the Tonga people in the Kafue

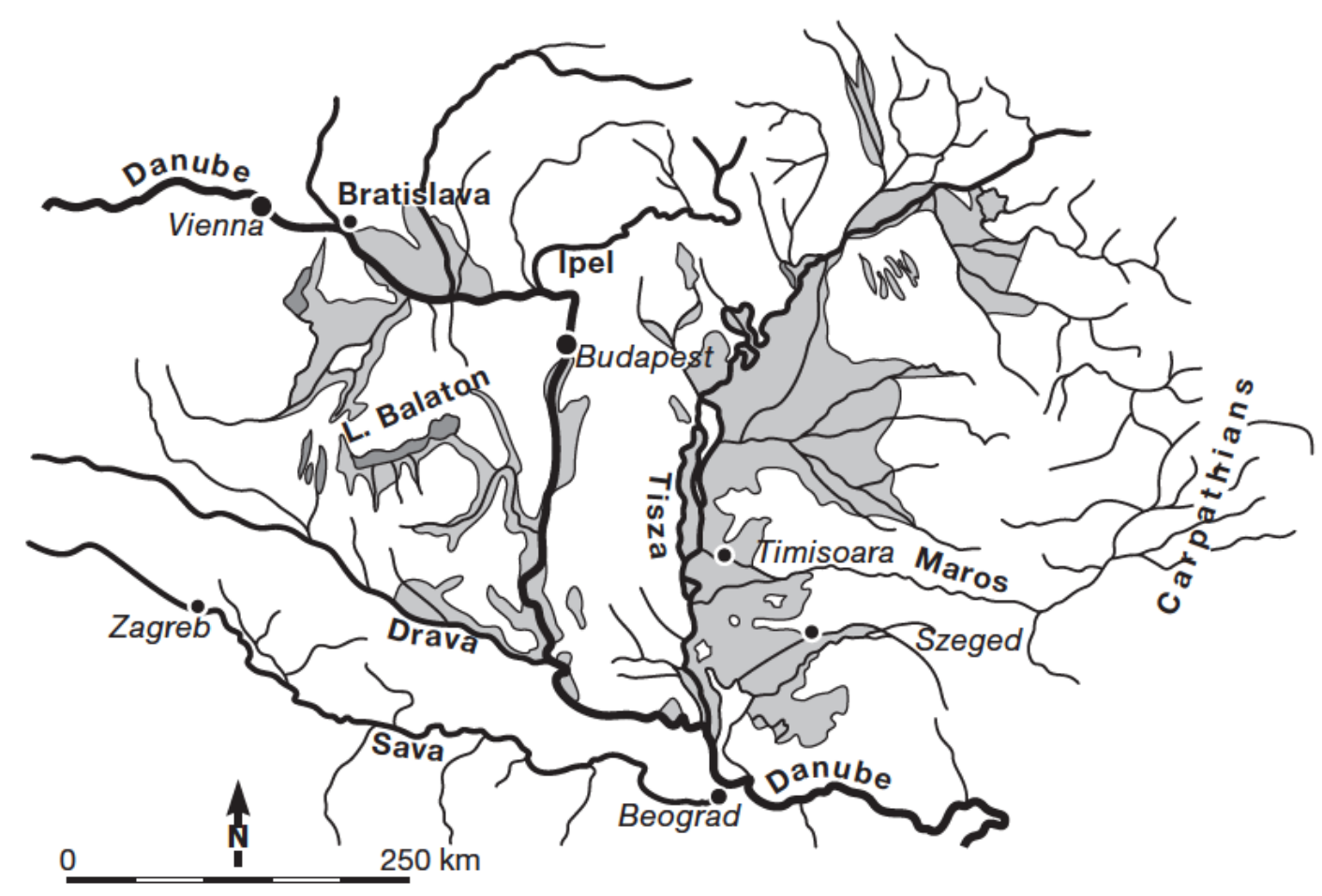

Figure 6 Former flood plains (grey areas) in Hungary and the neighbouring territories (redrawn from Czaya 1981). 
flood plain, or the Ogani in the Niger delta; the latter are threatened by oil exploitation in addition to changing hydrology. The Nuer, Dinka and Shiluk in the Sudd area (Nile) are threatened by civil war and by the construction of the Jonglai Canal (see Society for Threatened People, http://www.gfbv.de). The Mesopotamian 'Marsh Arabs' (population size: $350000-500000$ ), the ethnic link between present inhabitants of Iraq and the people ancient to Mesopotania, such as the Sumerans and Babylonians, are largely affected by the drying of wetlands, seeking refuge in nearby areas and urban centres (UNEP 2001).

\section{Changing floodplain structure}

A major way that fluvial processes influence biodiversity is the turnover of floodplain alluvium. One measure of turnover is the minimum age of the oldest parts of the floodplain sediment. Hughes (1997) reported sediment ages ranging from $100-600$ years for most minimally impacted alluvial rivers, and 2000 years for the Amazon. This means that different spatiotemporal scales have to be considered in order to evaluate the effect of anthropogenic and natural impacts on riverine flood plains (see Fig. 1). For example, the duration of floods has been the most important variable driving riparian dynamics of the Yampa River, Colorado, USA (Poiani et al. 2000). With no flooding the predicted abundance of mature cottonwood would decrease from $40 \%$ at present to about $20 \%$ within a period of about 120 years, and would disappear completely in about 450 years (Fig. $7 a$ ). A similar story has been documented for the Old Man River in Alberta, Canada (Rood \& HeinzeMilne 1989) and the Missouri River, Montana and South Dakota, USA (Johnson 1992). Flow stabilization below dams reduces floodplain size and flooded extent (Ward \& Stanford 1995; Molles et al. 1998; Snyder et al. 2002). The effects of this reduction include disruption of the riparian ecosystem, alterations of trophic structure, and reduced diversity of organisms highly adapted to periodic inundation and the associated input of nutrients and sediments. Along Alpine rivers (e.g. the Isar and the Lech; Fig. 7b), areas with secondary successional stages of vegetation expanded dramatically after dam construction, leading to $>90 \%$ decrease of pioneer communities within a period of less than 70 years. A post-dam equilibrium dominated by later successional species could be reached in about 150 years following dam closure. This projection excludes other potential land-use practices such as clearcutting. However, flow regulation can permit widespread development of novel wetlands such as the productive and diverse marshes as along the Colorado River downstream of Glen Canyon Dam (Stevens et al. 1995).

In Europe, dense floodplain forests (e.g. Petts et al. 1989) fringe formerly braided rivers (e.g. the Upper Danube). These extensive forests are largely an ecological legacy of past flooding. These stands, although considered as extremely worthy for protection, are senescent, and in the absence of flood disturbance will not be replaced. (a)

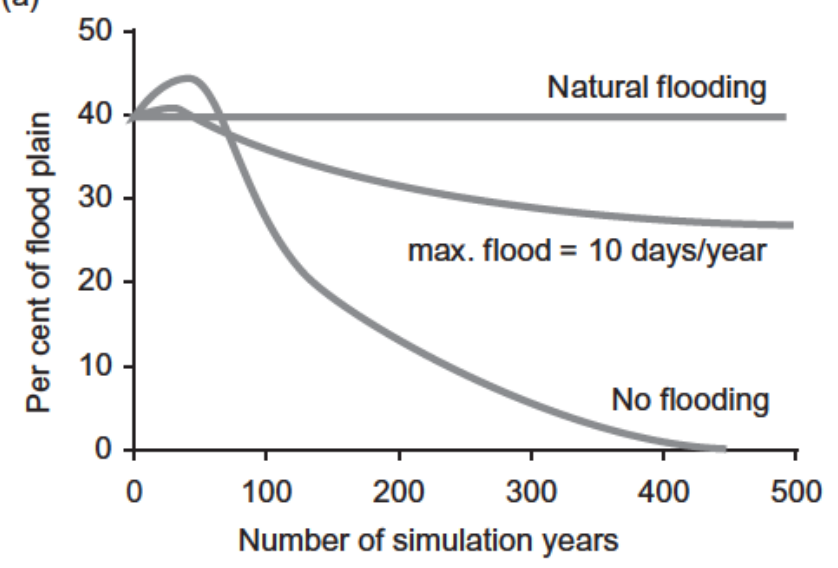

(b)



Figure 7 Changes in the riparian vegetation as a result of altered hydrology. (a) Simulation of riparian dynamics for the Yampa River in Colorado, USA. Variability in percentage of the flood plains occupied by mature cottonwood patches within the riparian ecosystem is predicted over a 500 -year period under three different flooding scenarios (after Poiani et al. 2000). (b) Headwater flood plains in the Northern Alps (Isar and Lech Rivers, Germany) showing decrease in floodplain area occupied by early successional stages of riparian vegetation since 1900 (after Reich 1994).

\section{Declining biodiversity}

In the near future, flood plains will remain among the most threatened systems, and they will disappear faster than any other wetland type. In particular, Asian, African and South American flood plains will disappear at accelerating rates. The twelve most species-rich countries (based on total number of species and number of fish species per $1000 \mathrm{~km}^{2}$ ) are all in the developing areas (except the USA which ranks sixth in total number of species), with gross primary productions of mostly $<\mathrm{US} \$ 1000 \mathrm{yr}^{-1}$ (based on the 1997 index). These countries will experience a rapid population growth combined with economic development that will increase the 
Table 7 Vertebrate species listed as endangered in Africa, Asia and the Americas (IUCN 2000). Many of the species listed are wetland/floodplain species.

\begin{tabular}{lrrrr}
\hline Group & Africa & Asia & $\begin{array}{l}\text { South } \\
\text { America }\end{array}$ & $\begin{array}{l}\text { North } \\
\text { America }\end{array}$ \\
\hline Fish & 104 & 216 & 103 & 190 \\
Amphibians & 12 & 47 & 27 & 27 \\
Reptilians & 29 & 104 & 76 & 35 \\
Bird & 53 & 521 & 353 & 84 \\
Mammals & 89 & 515 & 263 & 94 \\
Total & 287 & 1403 & 822 & 330 \\
\hline
\end{tabular}

pressure on their natural resources, in particular on fresh waters. The greatest decline in biodiversity is expected to occur in Asian fresh waters, where more than any other part of the world the most globally threatened ecosystems occur (Dudgeon 2002) and many more species are already listed as endangered (Table 7).

The projected mean future decline in aquatic biodiversity is about five times greater than the rate for terrestrial fauna and three times the rate for coastal marine areas. The rate of freshwater biodiversity decline is equivalent to the rate for tropical forest communities (Abramovitz 1996). For North America, for example, a future extinction rate of $4 \%$ per decade is predicted (Ricciardi \& Rasmussen 1999). In North America 40 freshwater fish species disappeared between 1880 and 1990, with a sharp increase in the past 30 years (Fig. 8a). Although fish are among the best-investigated freshwater groups, many fish species will go extinct before they are discovered. During the past 10 years 200 new fish species have been described annually. The causes of extinction of freshwater fishes are habitat degradation (78\%), introduction of exotics (68\%), pollution and hybridization (38\% each) and overharvest (15\%).

The global population database comprises 4500 time series over 1800 animal species. This is an important resource of information in tracing long-term trends; however, it contains almost no wetland or floodplain species (NERC [National Environment Research Council] 1999). The Freshwater Ecosystems Index, based on the population trends of 102 freshwater vertebrate species for which timeseries population data could be obtained, demonstrates an alarming density decline of freshwater vertebrate populations in the developed word (WWF 1999). On average, freshwater populations declined by about $45 \%$ between 1970 and 1995 , compared to $35 \%$ for marine systems (Fig. $8 b$; WWF 1999). Although not specifically indicating the trend for wetlands or flood plains, this index includes many characteristic floodplain species (e.g. many mammals or amphibians). We may expect an even sharper decrease for wetland species, since a higher proportion of their species is endangered (cf. Table 2). Overexploitation of natural flood plains not only leads to biotic impoverishment, it also limits opportunities for developing a fuller understanding of the processes operating in (a)

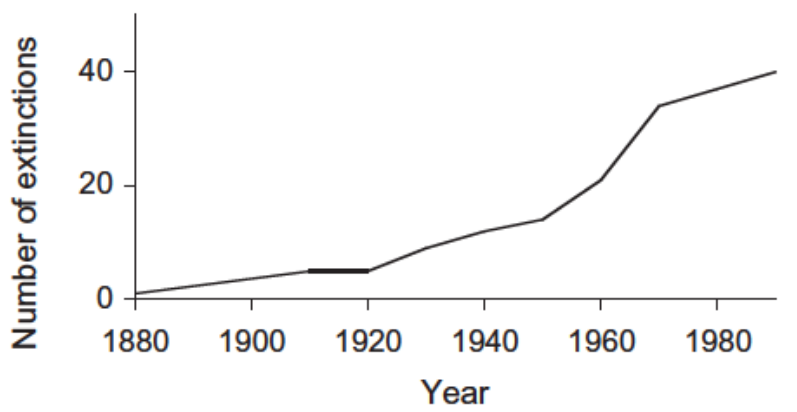

(b)

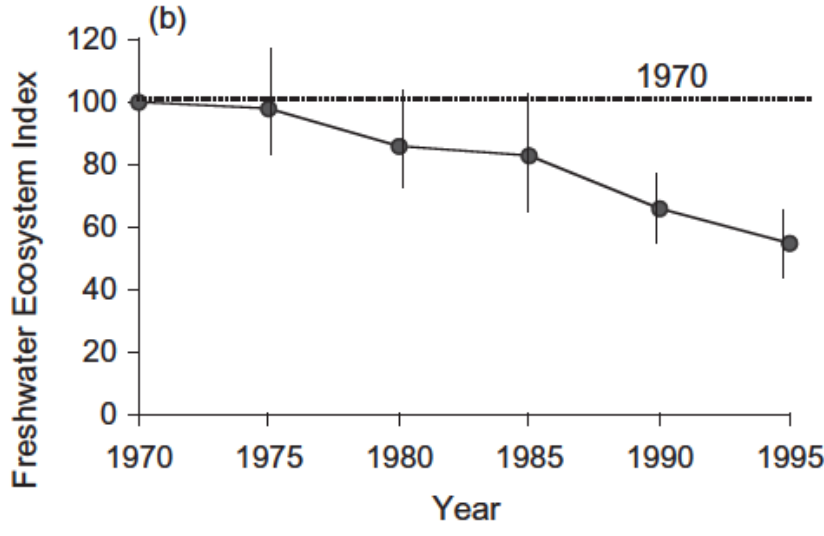

(c)

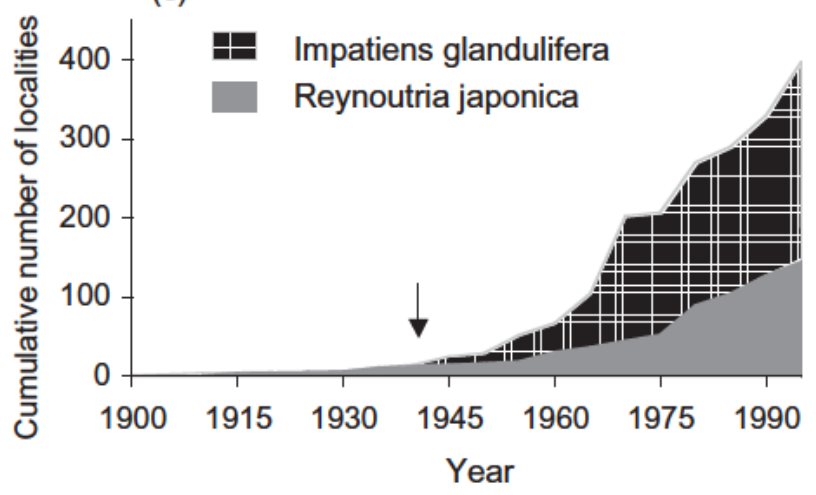

Figure 8 Long-term trends in freshwater systems: (a) cumulative fish extinctions in North America from 1880 to 1990 (Stiassny 1996), (b) Freshwater Ecosystem Index (average and 95\% confidence limits) showing long-term decline of freshwater vertebrate populations (WWF 1999; see text for further explanation), and $(c)$ invasion of riparian habitats in the Czech Republic by Impatiens glandulifera and Reynoutria japonica. Arrow marks the beginning of the exponential phase of population growth (redrawn from Pysek \& Prach 1993).

these dynamic systems. For example, the limited knowledge of the dynamic hydrologic-morphologic interactions in natural wetlands/flood plains is the primary reason that so many restoration projects fail. About $80 \%$ of restoration projects examined by Lockwood and Pimm (1999) did not meet their major goals. 


\section{Increasing invasion}

Novel disturbances such as clear-cutting or intensification of natural disturbances such as siltation play a significant role in biotic invasion. The progression from immigrant to invader often involves a lag phase, followed by a phase of exponential increase that continues until reaching the bounds of its new range (see Fig. 8c). This makes it difficult to predict future invaders. For example, Impatiens glandulifera, native to the Himalayas, has invaded large areas of European and North American flood plains. Like many other invaders, it reduces the fitness of competitors, in this case simply by attracting many more pollinators (e.g. Chittka \& Schürkens 2001). In the Czech Republic, Impatiens glandulifera and Reynoutria japonica (alien species from the Far East) exhibited exponential invasion rates after a lag phase of several decades. The time at which the exponential increase commenced was around 1940 for both species. Nowadays, they occupy more than 400 (I. glandulifera) and about $150(R$. japonica) riparian localities in the Czech Republic (Fig. 8c). Ongoing rapid anthropogenic alterations of riverine flood plains will increase the proliferation of such invading species.

\section{POTENTIAL STATUS IN 2025}

Although perhaps more severe, the major ecological consequences that we may expect by 2025 for flood plains are similar to those predicted for most aquatic systems (Naiman \& Turner 2000; Malmqvist \& Rundle 2002). The projected changes will be manifest as what has been termed the 'distress syndrome' (sensu Rapport \& Whitford 1999), indicated by reduced biodiversity, altered primary and secondary productivity, reduced nutrient cycling, increased prevalence of diseases, increased dominance of invaders and a predominance of shorter-lived opportunistic species. Since many flood plains respond very slowly to anthropogenic impacts, the ultimate effect of a given impact may be even more severe that expected from short-term projections. Hydrological change and channelization have generated shifts in the physical habitat that will take sufficiently long to be reflected by the long-lived biotic elements of the flood plains (e.g. Hughes 1997). This means that the lag time differs between abiotic changes and biotic adjustments. Therefore, a high biodiversity still observed in many regulated flood plains has to be considered as a relict of former conditions, since unidirectional development of the flood plain can be slow but will finally lead to a substantial decrease in diversity and major shift in community composition.

Today, over $60 \%$ of the world population live within $1 \mathrm{~km}$ of surface water, primarily along rivers and along the coastline. Increasing urbanization in the developing countries will further increase the land-use pressure on riparian systems. By the year 2025, $60 \%$ of the projected eight billion humans are expected to live in large cities. The low intensity of present land use along rivers in Africa and Asia, compared to Europe and the Americas, is primarily due to the low rate of urbanization. Present urban growth rates in major African catchments range from $3.6 \% \mathrm{yr}^{-1}$ in the Limpopo to $8.8 \%$ $\mathrm{yr}^{-1}$ in the Lake Tanganyika catchment (Ravenga et al. 1998). In the Mekong catchment, the population is projected to double within the next 25 years and the basin's economy to increase by $400 \%$ (Shiklomanov 1998). Increasing population growth and food production will further alter the global nitrogen cycle. By 2020 the global production of nitrogen fertilizer could increase to $134 \mathrm{Gt} \mathrm{yr}^{-1}$ from a level of 80

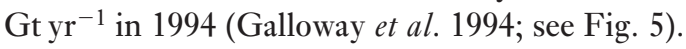

The 21st century has been proposed as the century of nature restoration. By 2025 an area equivalent to the size of the entire Great Lakes basin in North America, and water courses equivalent to the combined lengths of the Rhone and Rhine rivers, are expected to be restored to full health throughout the world (IUCN 2000). Such predictions may, however, be overly optimistic. For example, although 15000 $\mathrm{km}$ of streams and rivers in Switzerland have been identified for restoration programmes, the annual rate of river-floodplain restoration is only $11 \mathrm{~km}$ compared to $70 \mathrm{~km}$ lost during the same period by regulation (BUWAL 1993). Even if further degradation were to cease, it would take more than 1000 years to restore Switzerland's rivers and streams. Even this is an optimistic prediction, since it ignores the limited ecological success of most restoration projects.

Optimistic predictions (e.g. IUCN 2000) contrast sharply with the projected increases in population, water abstraction and economic development. The impending global-scale changes in human population and economic development over the 2025 time horizon will dictate the future relation between water supply and demand to a much greater degree than any other factor (e.g. Vörosmarty et al. 2000). The uncertainties in the changes in hydrology predicted for many regions translate to even greater uncertainties in how regional-scale biodiversity and biogeochemical cycles may change (Jackson et al. 2001a). In 2025, 48\% of the world's projected population is projected to live in water-stressed basins (Johnson et al. 2001). Since growing water scarcity is intimately linked to the alarming decline in aquatic biodiversity, a major decline in aquatic biodiversity may be realized by 2025 , particularly in the developing world. Together with waters in xeric regions and cataracts, riverine flood plains are the most threatened freshwater ecosystems (Olson \& Dinerstein 1998; Hughes \& Rood 2001). A change in the ecological status of flood plains is closely linked to hydrologic change. Even small decreases in flood volumes can result in large reductions in area flooded, particularly in semi-arid and arid areas. In the Murray-Darling basin (Australia), 87\% of divertible water resources are already diverted, leaving almost no water for flood plains (Kingsford 2000).

In 2025, the most water-stressed countries will be located in Africa and in Asia. In 1989 a continent-wide water crisis was predicted for Africa for the year 2025, when 22 countries with two-thirds of the continent's population would be water stressed (Falkenmark 1989). Careful cost/benefit calculation of the services provided by natural flood plains are required 
to develop the rationale needed for their future preservation. In South America, many flood plains will become reduced in size, including extensive flood plains along the large (sub)tropical rivers. Pollution from expanding mega-cities, hydropower generation, construction of large navigation canals (e.g. crossing the Pantanal), and ongoing deforestation are the primary threats to South American flood plains (Junk 2002).

By 2025, an optimistic prediction for developed countries is to achieve a balance between river kilometres restored annually and those regulated annually. The lack of reference data from pristine systems, however, constrains the capability to restore flood plains and mitigate damage to them. In North America, the commendable policy of 'no net loss' of wetlands will nonetheless not prevent further degradation of seminatural flood plains. Reconstructed wetlands and flood plains that are subject to large restoration programmes (e.g. Kissimmee, Mississippi) can only provide a pale reflection of their dynamic natural state. Moreover, we should be aware that it is easy to underestimate the degradation of flood plains because of their naturally high ecological resistance and resilience and the extended lag phase before the severity of human impacts becomes readily apparent. Ecological diversity and redundancy within trophic levels, coupled with the longevity of the most obvious species (trees, fish), are the most important reasons for delay between impact and ecological response; eventually, however, a sudden collapse of the entire ecosystem is to be expected. For comparison, in marine systems time lags of decades to centuries occurred between the onset of overfishing and consequent changes in ecological communities (Jackson et al. 2001b).

Most remaining and protected floodplain fragments in Europe and North America are in danger of becoming 'sinks' for their wildlife. In Switzerland, for example, more than $40 \%$ of the riparian-obligate species are listed as endangered (Table 2). These obligates are living in a highly fragmented landscape, and many populations can be expected to become extinct within the next decades, even if those flood plains are preserved.

The concept of 'minimum dynamic area' has already become an important consideration in the design of conservation areas (Poiani et al. 2000). Large-scale disturbances such as major flood events create a diverse, shifting mosaic of successional stages and habitats of different types and sizes (Ward et al. 2002). The minimum dynamic area must provide room for the geomorphic processes that reshape the flood plain and create and rejuvenate the complete array of patch types. Riparian ecosystems are dependent upon disturbance caused by occasional high flows. Resource managers concerned with maintaining floodplain systems need to consider ways to preserve flows that are crucial to the survival of native riparian species. One of the main lessons from the past 100 years of river-floodplain control is that to sustain the integrity of large alluvial rivers, restoration must find a place for change by 'changing flows (certainly) and moving channels (ideally)’ (Petts 1996).

\section{CONCLUSIONS}

This analysis of the present and future state of riverine flood plains conveys a dismal prognosis indeed, despite recognition of the important services provided by these ecosystems. Perhaps the only hope for sustaining functional flood plains over the long term lies with highly enlightened management and restoration efforts.

As a first step a global database on the location and size of wetlands in general and flood plains and their complex wetlands in particular is urgently needed. Major biophysical features, including information on the expansion/contraction of floodplain areas and the timing of floods (see Table 5) must be included in this assessment. In a second step, a compilation of threats, land tenure, management and studies on the benefits and values of different wetland types are required. A third step is to initiate greater conservation of flood plains through creation of floodplain natural areas and riparian greenbelts along the entire corridors of rivers from headwaters to mouth. Conservation easements and purchases to silence development rights (e.g. for gravel mining and exurban development) to protect remaining intact flood plains are urgently needed. Natural uses of flood plains far outweigh the value of human activities that constrain floodplain structure and function. Finally, a more robust and predictive understanding of how changes in hydrological connectivity and habitat fragmentation affect floodplain communities is required to foster better and more proactive conservation practices. Flood plains need to be understood by the general public for the values they provide in the form of natural goods (harvestable fisheries) and services (natural cleansing of water).

Of course, many questions remain about floodplain ecology that need to be investigated within the next decades. They include: the synergistic effects of 'stressors', the identification of ecological thresholds, the minimum dynamic areas required for basic ecological functions, such as nutrient retention and transformation, long-term trends in floodplain populations, the role of flood plains in controlling processes at the catchment and corridor scale, and the interactions between aquatic and terrestrial communities. However, we must act now to protect these valuable ecosystems, based on the incomplete yet considerable information available. Restoration projects, carefully planned and monitored, may serve as large-scale field experiments for a better understanding of the dynamics and complexity of riverine flood plains.

Non-governmental organizations and multinational institutions such as IUCN, UNEP, UNESCO, Worldwatch Institute, World Resource Institute, WWF, Ramsar Bureau, Nature Conservancy or Birdlife International, among many others, play a leading role in transferring basic research information to the public and to decision makers and in securing protection for biodiversity hot spots. Their role in conserving and restoring flood plains and wetlands must increase in the near future in relation to the fast-growing 
scientific knowledge about the strategic importance of flood plains to healthy rivers that parallels the accelerating deterioration of remaining systems.

The clear and unavoidable conclusion is that governments must find the will and way to preserve existing intact flood plain rivers as strategic global resources, and begin to restore hydrologic dynamics, sediment transport and riparian vegetation to those rivers that retain some level of ecological integrity. Flood plains must be viewed as conservatories of regional biodiversity and as fundamental units of river ecosystems that facilitate clean water and provide renewable timber, fisheries and wildlife resources, among many other natural goods and services. Most importantly, flood plains are natural flood control structures and they should be used that way. Indeed, recent horribly-damaging floods on the Mississippi River (USA) and elsewhere clearly were exacerbated by the very revetments that were designed to allow human encroachment onto the flood plains. A new era of naturalization of flood plains is needed to protect the integrity of river corridors. Flood plains designated for conservation or restoration must be large enough to support key species and perform key functions. Conducting protection and restoration on small reaches, without considering longitudinal linkages of flood plains throughout their catchment basin, will simply not work. Rather, an expansive catchment view of river landscapes is required, a leitbild or set of normative conditions that restores enough flow and sediment to produce variability of landscape form within river corridors. Possible constraints on river flow must be removed so that flood plains can function in a normative way, allowing the river to do the conservation and restoration of floodplain habitats, as opposed to using heavy equipment to artificially engineer solutions (sensu Stanford et al. 1996). The goal is to maximize human benefits by capitalizing on the natural functional attributes of river landscapes for flood and drought control and maintenance of biota. Otherwise, a dramatic extinction of aquatic and riparian species and of ecosystem services is to be expected by 2025 and in the decades following.

\section{ACKNOWLEDGEMENTS}

We are very grateful to Professor J.V. Ward and to Drs David Galat, Tom Buijse, Brij Gopal and Nicholas Polunin for valuable comments on earlier versions of the manuscript and to three anonymous reviewers for their constructive criticisms. We also thank Dr Nicholas Polunin and The Foundation for Environmental Conservation for support.

\section{References}

Abernethy, R.K. \& Turner, R.E. (1987) US forested wetlands: 1940-1980. BioScience 37: 721-727.

Abramovitz, J.N. (1996) Imperiled waters, impoverished future: the decline of freshwater ecosystems. Worldwatch Paper 128. Washington DC, USA: Worldwatch Institute.
Abu Zeid, M. (1989) Environmental impacts of the Aswan High Dam. Water Resources Development 5: 147-157.

Al Hamed, M.I. (1966) Limnological studies on the inland waters of Iraq. Bulletin of the Iraq Natural History Museum 3: 1-22.

Anderson, M.G., Walling, D.E. \& Bates, P.D., eds. (1996) Floodplain Processes. Chichester, UK: Wiley.

Andréasson-Gren, I.-M. \& Groth, K.-H. (1995) Economic evaluation of Danube floodplains. Unpublished report, WWF International, Gland, Switzerland.

Aselman, I. \& Crutzen, P.J. (1989) Global distribution of natural wetlands and rice paddies, their net primary productivity, seasonality and possible methane emissions. Fournal of Atmospheric Chemistry 8: 307-358.

Bailey, R.G., José, P.V. \& Sherwood, B.R, eds. (1998). United Kingdom Floodplains. Otley, West Yorkshire, UK: Westbury Academic and Scientific Publishing.

Baker, J.A., Killgore, K.J. \& Kasul, R.L. (1991) Aquatic habitats and fish communities in the lower Mississippi River. Reviems in Aquatic Sciences 3: 313-356.

Barbier, E.B. \& Thompson, J.R. (1998) The value of water: floodplain versus large-scale irrigation benefits in Northern Nigeria. Ambio 27: 434-440.

Batzer, D.P., Rader, R.B. \& Wissinger, S.A., eds. (1999) Invertebrates in Freshmater Wetlands of North America. New York, USA: Wiley.

Bayley, P.B. (1988) Accounting for effort when comparing tropical fisheries in lakes, river-floodplains, and lagoons. Limnology and Oceanography 33: 963-972.

Bayley, P.B. (1995) Understanding large river-floodplain ecosystems. BioScience 45: 143-158.

Bedford, B.L. (1996) The need to define hydrologic equivalence at the landscape scale for freshwater wetland mitigation. Ecological Applications 6: 57-68.

Benayas, J.M.R., Colomer, M.G.S. \& Levassor, C. (1999) Effects of area, environmental status and environmental variation on species richness per unit area in Mediterranean wetlands. Fournal of Vegetation Science 10: 275-80.

Benke, A.C. (1990) A perspective on America's vanishing streams. Fournal of the North American Benthological Society 9: 77-88.

Benke, A.C., Chaubey, I., Ward, M. \& Dunn, E.L. (2000) Flood pulse dynamics of an unregulated river floodplain in the Southeastern U.S. coastal plain. Ecology 81: 2730-2741.

Bravard, J.P. (1987) Le Rhône du Léman à Lyon. Lyon, France: La Manufacture.

Brinson, M.M. (1990) Riverine forests. In: Forested Wetlands, ed. A.E. Lugo, M.M. Brinson \& S. Brown, pp. 87-141. Amsterdam, The Netherlands: Elsevier.

Brinson, M.M. \& Malvárez, A.I. (2002) Temperate freshwater wetlands: types, status, and threats. Environmental Conservation 29: 115-133.

Brown, A.G., Stone, P. \& Harwood, K. (1995) The biogeomorphology of a wooded anastomosing river: the Gearagh on the River Lee in County Cork, Ireland. Occasional Paper 32, University of Leicester, UK.

Buijse, A.D., Coops, H., Staras, M., Jans, L.H., Van Geest, G.J., Grift, R.E., Ibelings, B.W., Oosterberg, W. \& Roozen, F.C.J.M. (2002) Restoration strategies for river floodplains along large lowland rivers in Europe. Freshmater Biology 47: 889-907.

Bulgarian Ministry of Agriculture and Forests (2001) Strategy for the protection and restoration of floodplain forests on the 
Bulgarian Danube islands. Unpublished Report. Vienna, Austria. WWF International Danube Carpathian Programme.

Burby, R.J. (2002) Flood insurance and floodplain management: the US experience. Environmental Hazards (in press).

Busnita, T. (1967) Die Ichthyofauna der Donau. In: Limnologie der Donau, ed. R. Liepolt, pp. 198-224. Stuttgart, Germany: Schweizerbart'sche Verlagsbuchhandlung.

BUWAL (1993) Kartierung der Auengebiete von nationaler Bedeutung. Schriftenreihe Umwelt 199, Bern, Switzerland.

Carbiener, R. \& Schnitzler, A. (1990) Evolution of major pattern models and processes of alluvial forests of the Rhine in the rift valley (France/Germany). Vegetatio 88: 115-129.

Carling, P.A. \& Petts, G.E., eds. (1992) Lomland Floodplain Rivers. Geomorphic Perspectives. Chichester, UK: Wiley.

Chittka, L. \& Schürkens, S. (2001) Successful invasion of a floral market. Nature 411: 653 .

Cleverly, J.R., Smith, S.D., Sala, A. \& Devitt, D.A. (1997) Invasive capacity of Tamarix ramosissima in the Mojave Desert floodplain: the role of drought. Oecologia 111: 12-18.

Congressional Natural Hazards Caucus Work Group (2001) Discussion paper for the Congressional Natural Hazards Caucus [www document]. URL http://www.agiweb.org/workgroup.

Constanza, R., d'Arge, R., de Groot, R., Farber, S., Grasso, M., Hannon, B., Limburg, K., Naeem, S., Neill, R.V., Paruelo, J., Raskin, R.G., Sutton P. \& Van der Belt, M. (1997) The value of the world's ecosystem services and natural capital. Nature 387 : 253-260.

Cosgrove, W.J. \& Rijsberman, F.R. (2000) World Water Vision. London, UK: Earthscan.

Czaya, E. (1981) Rivers of the World. New York, USA: Van Nostrand Reinhold Company.

Dadnadji, K.K. \& Van Wetten, J.C.J. (1993) Traditional management systems and irrigation of small scale interventions in the Lagone floodplains of Chad. In: Tomards the Wise Use of Wetlands, ed. T.J. Davis, pp. 74-81. Gland, Switzerland: Ramsar Convention Bureau.

DHI Water \& Environment (2001) Yellow River flood management sector project, China (2000). Unpublished report, Horsholm, Denmark.

Dudgeon, D. (2000a) Conservation of freshwater biodiversity in Oriental Asia. Constraints, conflicts, and challenges to science and sustainability. Limnology 1: 237-243.

Dudgeon, D. (2000b) The ecology of tropical Asian streams in relation to biodiversity conservation. Annual Reviem of Ecology and Systematics 31: 239-263.

Dudgeon, D. $(2000 c)$ Large-scale hydrological changes in tropical Asia: Prospects for riverine biodiversity. BioScience 50: 793-806.

Dudgeon, D. (2002) The most endangered ecosystems in the world? Conservation of riverine biodiversity in Asia. Verhandlungen der Internationalen Vereinigung für Theoretische und Angemandte Limnologie (in press).

Dugan, P.J., ed. (1990) Wetland Conservation: a Reviem of Current Issues and Required Action. Gland, Switzerland: IUCN.

Falkenmark, M. (1989) The massive water scarcity now threatening Africa-Why isn't it being addressed? Ambio 18: 112-118.

FAO (1999) Review of the state of world fishery resources: inland fisheries. FAO Fisheries Circular 942. Food and Agriculture Organization of the United Nations, Rome, Italy.

FAO (2001) Asia-Pacific Conference on Early Warning, Prevention, Preparedness, and Management of Disasters in Food and
Agriculture. Unpublished report. Food and Agriculture Organization of the United Nations, Rome, Italy.

Finlayson, C.M. \& Davidson, N.C. (1999) Global review of wetland resources and priorities for wetland inventory: summary report. Unpublished report, Wetlands International and Jabiru, Wageningen, The Netherlands.

Fittkau, E.J. \& Reiss, F. (1983) Versuch der Rekonstruktion der Fauna der europäischen Ströme und ihrer Auen. Archiv für Hydrobiologie 97: 1-6.

Foundation for Environmental Conservation (2001) An introduction to long-term environmental trends [www document]. URL http://www.ncl.ac.uk/icef

Fremlin, G., ed. (1974) The National Atlas of Canada. 4th Edition. Toronto, Canada: Macmillan.

Galloway, J.N., Levy II, H. \& Kasibhatla, P.S. (1994) Year 2020: consequences of population growth and development on the deposition of oxidized nitrogen. Ambio 23: 120-123.

Galat, D.L., Fredrickson, L.H., Humburg, D.D., Bataille, K.J., Bodie, J.R., Dohrenwend, J., Gelwicks, G.T., Havel, J.E., Helmers, D.L., Hooker, J.B., Jones, J.R., Knowlton, M.F., Kubisiak, J., Mazourek, J., McCoplin, A.C., Renken, R.B. \& Semlitsch, R.D. (1998) Flooding to restore connectivity of regulated, large-river wetlands. BioScience 48: 721-733.

Galat, D.L. \& Zweimüller, I. (2001) Conserving large-river fishes: is the highway analogy an appropriate paradigm? Fournal of the North American Benthological Society 20: 266-279.

Gladden, J.E. \& Smock, L.A. (1990) Macroinvertebrate distribution and production on the floodplains of two lowland headwater streams. Freshmater Biology 24: 533-545.

Gleick, P.H. (2000) The World's Water: 2000-2001. Washington DC, USA: Island Press.

Gill, A.M., Ryan, P.G., Moore, P.H.R. \& Gibson, M. (2000) Fire regimes of World Heritage National Park, Australia. Austral Ecology 25: 616-625.

Gopal, B., Junk, W.J. \& Davis, J.A., eds. (2000) Biodiversity in Wetlands: Assessment, Function and Conservation. Volume 1. Leiden, The Netherlands: Backhuys Publisher.

Gopal, B., Junk, W.J. \& Davis, J.A., eds. (2002) Biodiversity in Wetlands: Assessment, Function and Conservation. Volume 2. Leiden, The Netherlands: Backhuys Publisher.

Gregory, S.V., Swanson, F.J., McKee, W.A. \& Cummins, K.W. (1991) An ecosystem perspective of riparian zones. BioScience 41: $540-551$.

Groombridge, B. (1992) Global Biodiversity. Status of the Earth's Living Resources. London, UK: World Conservation Monitoring Centre and Chapman \& Hall.

Hamilton, S.K. \& Lewis, W.M., Jr (1990) Physical charcteristics of the fringing floodplain of the Orinoco River, Venzuela. Intersciencia 15: 491-500.

Hamilton, S.K., Sippel, S.J. \& Melack, J.M. (1996) Inundation patterns in the Pantanal wetland of South America determined by passive microwave sensing. Archiv für Hydrobiologie 137: 1-23.

Haraszthy, L. (2001) The floodplain forests in Hungary. In: The Floodplain Forests in Europe, ed. E. Klimo \& H. Hager, pp. 17-24. Leiden, The Netherlands: Brill.

Heckman, C.W. (1998) The Pantanal of Poconé. Dordrecht, The Netherlands: Kluwer Academic Publisher.

Heeg, J. \& Bren, C.M. (1982) Man and the Pongolo floodplain. South African National Scientific Report 56, Pretoria, South Africa. 
Hollis, G.E., Adams, W.M. \& Aminu-Kano, M. (1993) The Hadejia-Nguru wetlands. Unpublished report, IUCN, Gland, Switzerland.

Hood, G.W. \& Naiman, R.J. (2000) Vulnerability of riparian zones to invasion by exotic vascular plants. Plant Ecology 148: 105-114.

Howard-Williams, C. \& Thompson, K. (1985) The conservation and management of African wetlands. In: The Ecology and Management of African Wetland Vegetation, ed. P. Denny, pp. 203-230. Dordrecht, The Netherlands: Junk.

Hughes, F.M.R. (1988) The ecology of floodplain forests in semiarid and arid zones: a review. Fournal of Biogeography 15: 127-140.

Hughes, F.M.R. (1997) Floodplain biogeomorphology. Progress in Physical Geography 21: 501-529.

Hughes, F.M.R. \& Rood, S.B. (2001) Floodplains. In: Habitat Conservation: Managing the Physical Environment, ed. A. Warren \& J.R. French, pp. 105-121. Wiley, UK: Chichester.

IPCC (2001) Climate change 2001: impacts, adaptations and vulnerability. Contribution of Working Group II to the Third Assessment Report of the Intergovernmental Panel on Climate Change [www document]. URL http://www.ipcc.ch/pub/tar/wg2/index.htm

IUCN (2000) Vision for Water and Nature. A World Strategy for Conservation and Sustainable Management of Water Resourcs in the 21st Century. Gland, Switzerland: The World Conservation Union.

Ittekot, V., Humborg, C. \& Schaefer, P. (2000) Hydrological alterations and marine biogeochemistry: a silicate issue? BioScience 50: $776-782$.

Jackson, R.B., Carpenter, S.R., Dahm, C.N., McKnight, D.M., Naiman, R.J., Postel S.L. \& Running, S.W. (2001a) Water in a changing world. Ecological Applications 11: 1027-1045.

Jackson, J.B, Kirby, M.X., Berger, W.H., Bjorndal, K.A., Botsford, L.W., Bourque, B.J., Bradbury, R.H., Cooke, R., Erlandson, J., Estes, J.A., Hughes, T.P., Kidwell, S., Lange, C.B., Lenihan, H.S., Pandolfi, J.M., Peterson, C.H., Steneck, R.S., Tegner, M.J. \& Warner, R.R. (2001b) Historical overfishing and the recent collapse of coastal ecosystems. Science 293: 629-637.

Johnson, N., Revenga, C. \& Echeverria, J. (2001) Managing water for people and nature. Science 292: 1071-1072.

Johnson, W.C. (1992) Dams and riparian forests: case study from the upper Missouri River. Rivers 3: 229-242.

Jolly, I.D. (1996) The effects of river management on the hydrology and hydroecology of arid and semi-arid floodplains. In: Floodplain Processes, ed. M.G. Anderson, D.E. Walling \& P.D. Bates, pp. 577-609. Chichester, UK: Wiley.

Junk, W.J., ed. (1997) The Central Amazon Floodplain. Berlin, Germany: Springer.

Junk, W.J. (2002) Long term environmental trends in tropical wetlands. Environmental Conservation 29: (in press).

Junk, W.J., Bayley, P.B. \& Sparks, R.E. (1989) The flood pulse concept in river-floodplain systems. Canadian Special Publication of Fisheries and Aquatic Sciences 106: 110-127.

Junk, W.J. \& Welcomme, R.L. (1990) Floodplains. In: Wetlands and Shallow Continental Water Bodies, ed. B.C. Patten et al., pp. 491-524. The Hague, The Netherlands: SPB Academic Publishers.

Keddy, P.A. (2000) Wetland Ecology. Principles and Conservation. Cambridge, UK: Cambridge University Press.

Kelsey, K.A. \& West, S.D. (1998) Riparian wildlife. In: River Ecology and Management. Lessons from the Pacific Coastal
Ecoregion. ed. R.J. Naiman \& R.E. Bilby, pp. 235-258. New York, USA: Springer.

Khalil, G.M. (1990) Flood in Bangladesh: a question of disciplining the river. Natural Hazards 3: 379-401.

Kingsford, R.T. (2000) Ecological impacts of dams, water diversions and river management on floodplain wetlands in Australia. Austral Ecology 25: 109-127.

Kingsford, R.T., Boulton, A.J. \& Puckridge, I.T. (1998) Challenges in managing dryland rivers crossing political boundaries: lessons from Cooper Creek and the Paroo River, central Australia. Aquatic Conservation 8: 361-378.

Kirkby, J. \& O'Keefe, P. (1998) Conservation of inland deltas: a case study of the Gash Delta, Sudan. In: The Sustainable Management of Tropical Catchments, ed. D. Harper \& A.G. Brown, pp. 209-223. Chichester, UK: Wiley.

Klimo, E. \& Hager, H., eds. (2001) The Floodplain Forests in Europe. Leiden, The Netherlands: Brill.

Knopf, F.L. \& Samson, F.B. (1994) Scale perspectives on avian diversity in western riparian ecosystems. Conservation Biology 8: 669-676.

Krist, L.P. \& Nebel, G. (2001) A review of Peruvian flood plain forests. Ecosystems, inhabitants and resource use. Forest Ecology and Management 150: 3-26.

Kusler, J. \& Larson, L. (1993) Beyond the ark: a new approach to US floodplain management. Environment 35: 7-35.

Lehmusluoto, P., Machbub, B., Terangna, N., Achmad, F., Boer, L., Brahmana, S., Setiadji, B., Priadie, B., Timtius, K.H. \& Goeltenboth, F. (1999) Limnology in Indonesia. In: Limnology in Developing Countries, Volume 2, ed. R.G. Wetzel \& B. Gopal, pp. 119-234. SIL.

Leopold, L.B., Wolman, M.G. \& Miller, J.P. (1964) Fluvial Processes in Geomorphology. New York, USA: Dover Publications.

Llewellyn, D.W., Shaffer, G.P., Craig, N.J., Creasman, L., Pashley, D., Swan M. \& Brown, C. (1996) A decision-support system for prioritizing restoration sites on the Mississippi River alluvial plain. Conservation Biology 10: 1446-1455.

Lockwood, J.L. \& Pimm, S.L. (1999) When does restoration succeed? In: Ecological Assembly Rules: Perspectives, Advances, Retreats, ed. E. Wieher \& P.A. Keddy, pp. 363-392. Cambridge, UK: Cambridge University Press.

Lu, J. (1995) Ecological significance and classification of Chinese wetlands. Vegetatio 118: 49-56.

Lugo, A.E., Brinson, M. \& Brown, S., eds. (1990) Ecosystems of the World. 15: Forested Wetlands. Amsterdam, The Netherlands: Elsevier.

Mackey, N. \& Eastburn, D., eds. (1990) The Murray. Canberra, Australia: Murray Darling Basin Commission.

Malanson G.P. (1993) Riparian Landscapes. Cambridge, UK: Cambridge University Press.

Malmqvist, B. \& Rundle, S. (2002) Threats to running water ecosystems of the world. Environmental Conservation 29: 134-153.

Margat, J. \& Vallee, D. (1999) Mediterranean vision on water, population and the environment for the XXIst century. MEDTAC, Plan Bleu.

Marsh, P., Lesack, L.F.W. \& Roberts, A. (1999) Lake sedimentation in the Mackenzie delta, NWT. Hydrological Processes 13: 2519-2536.

Megonigal, J.P., Conner, W.H., Kroeger, S. \& Sharitz, R.R. (1997) Aboveground production in southeastern floodplain forests: a test of the subsidy-stress hypothesis. Ecology 78: 370-384.

Mertes, L.A.K. (2000) Inundation hydrology. In: Inland Flood 
Hazards, ed. E.E. Wohl, pp. 145-166. Cambridge, UK: Cambridge University Press.

Middelkoop, H. \& Kwadijk, J.C.J. (2001) Towards integrated assessment of the implications of global change for wetland management - The Rhine experience. Phys. Chem. Earth (b) 26: $553-560$.

Middleton, B. (1999) Wetland Restoration, Flood Pulsing, and Disturbance Dynamics. New York, USA: Wiley.

Mirza, A.M.Q. (2002) Global warming and changes in the probability of occurrence of floods in Bangladesh and implications. Global Environmental Change (in press).

Mitsch, W.J. \& Gosselink, J.G. (2000) Wetlands. New York, USA: Wiley.

Molles, M.C., Jr, Crawford, C.S., Ellis, L.M., Valett, H.M. \& Dahm, C.N. (1998) Managed flooding for riparian ecosystem restoration. BioScience 48: 749-756.

Moore, P.D. (2002) The future of temperate bogs. Environmental Conservation 29: 3-20.

Muhar, S., Kainz, M., Kaufmann, M. \& Schwarz, M. (1998) Erhebung und Bilanzierung flusstypspezifisch erhaltener Fliessgewässerabschnitte in Österreich. Österreichische Wasser und Abfallwirtschaft 5/6:119-127.

Myers, M.F. \& White, G.F. (1993) The challenge of the Mississippi flood. Environment 35: 6-35.

Nachtnebel, H.-P. (2000) The Danube river basin environmental programme: plans and actions for a basin wide approach. Water Policy 2: 113-129.

Naiman, R.J. \& Decamps, H. (1997) The ecology of interfaces: riparian zones. Annual Revue of Ecology and Systematics 28: 621-658.

Naiman, R.J. \& Turner, M.G. (2000) A future perspective on North America's freshwater ecosystems. Ecological Applications 10: 958-970.

Naiman, R.J., Bilby, R.E. \& Bisson, P.A. (2000) Riparian ecology and management in the Pacific coastal rain forest. BioScience 50: 996-1011

NERC (1999) The Global Population Dynamics Database. Centre for Population Biology, Imperial College, Berkshire, UK [www document]. URL http://www.sw.ic.ac.uk/cpb/cpb/gpdd.html

Nilsson, C. \& Berggren, K. (2000) Alterations of riparian ecosystems caused by river regulation. BioScience 50: 783-792.

National Oceanic and Atmospheric Administration-National Geophysical Data Center (1998) Stable lights and radiance calibrated lights of the world. CD-ROM, Boulder, Colorado, USA. URL http://spir.noaa.gov

Oleksyn, J. \& Reich, P.B. (1994) Pollution, habitat destruction, and biodiversity in Poland. Conservation Biology 8: 943-960.

Olson, D.M. \& Dinerstein, E. (1998) The global 200: a representation approach to conserving the earth's most biologically valuable ecosystems. Conservation Biology 12: 502-515.

Pantulu, V.R. (1986) The Mekong river system. In: The Ecology of River Systems, ed. B.R. Davies \& K.F. Walker, pp. 695-719. The Hague, The Netherlands: W.Junk.

Penka, M., Vyskot, M., Klimo, E. \& Vašíček, F., eds. (1985) Floodplain Forest Ecosystem. I. Before Water Management Measures. Praha, Czech Republic: Academia.

Penka, M., Vyskot, M., Klimo, E. \& Vašíček, F., eds. (1991) Floodplain Forest Ecosystem. II. After Water Management Measures. Praha, Czech Rebublic: Academia and Elsevier.

Petts, G.E., Möller, H. \& Roux, A.L., eds. (1989) Historical Change of Large Alluvial Rivers: Western Europe. Chichester, UK: Wiley.
Petts, G. (1990) Forested river corridors: a lost resource. In: Water, Engineering, and Landscapes: Water Control and Landscape Transformation in the Modern Period, ed. D. Cosgrove \& G.E. Petts, pp. 12-34. London, UK: Belhaven Press.

Petts, G.E. (1996) Sustaining the ecological integrity of large river floodplain systems. In: Floodplain Processes, ed. M.G. Anderson, D.E. Walling \& P.D. Bates, pp. 535-551. Chichester, UK: Wiley.

Perelman, S.B., Leon, J.C. \& Oesterheld, M. (2001) Cross-scale vegetation patterns of Flooding Pampa grasslands. Fournal of Ecology 89: 562-577.

Poiani, K.A., Richter, B.D., Anderson, M.G. \& Richter, H.E. (2000) Biodiversity conservation at multiple scales: functional sites, landscapes, and networks. BioScience 50: 133-146.

Prach, K., Jenik, J. \& Large, A.R.G., eds. (1996) Floodplain Ecology and Management. The Luznice River in the Trebon Biosphere Reserve, Central Europe. The Hague, The Netherlands: SPB Academic Publishing.

Pringle, C.M. (2001) Hydrologic connectivity and the management of biological reserves: a global perspective. Ecological Applications 11: 981-998.

Pysek, P. \& Prach, K. (1993) Plant invasion and the role of riparian habitats: a comparison of four species alien to central Europe. Journal of Biogeography 20: 413-420.

Ramsar \& IUCN (1999) Wetlands and global change [www document]. URL http://www.ramsar.org/key_unfccc_bkgd.htm

Rapport, D.J. \& Whitford, W.G. (1999) How ecosystems respond to stress. BioScience 49: 193-203.

Ravenga, C., Brunner, J., Henninger, N., Kassem, K. \& Payne, R. (2000) Pilot Analysis of Global Ecosystems. Freshmater Systems. Washington DC, USA: World Resources Institute.

Ravenga, C., Murray, S., Abramovitz, J. \& Hammond, A. (1998) Watersheds of the World. Washington DC, USA: World Resources Institute.

Reich, M. (1994) Les impacts de l'incision des rivières des alpes bavaroises sur les communautés terrestres de leur lit majeur. Revue de Geographie de Lyon 69: 25-30.

Ricciardi, A. \& Rasmussen, J.B. (1999) Extinction rates of North American freshwater fauna. Conservation Biology 13: 1220-1222.

Richter, B.D., Braun, D.P., Mendelson, M.A. \& Master, L.L. (1997) Threats to imperiled freshwater fauna. Conservation Biology 11: 1081-1093.

RIZA (2000) Ecological Gradients in the Danube Delta Lakes. RIZA report 2000.015, The Netherlands (ISBN 90.369.5309x).

Rood, S.B. \& Heinze-Milne, S. (1989) Abrupt downstream forest decline following river damming in southern Alberta. Canadian Fournal of Botany 67: 1744-1749.

Roshier, D.A., Roberson, A.I. \& Kingsford, R.T. (2002) Responses of waterbirds to flooding in an arid region of Australia and implications for conservation. Biological Conservation 106: 399-411.

Rzoska J. (1974) The Upper Nile swamps, a tropical wetland study. Freshwater Biology 4: 1-30.

Sahagian, D. \& Melack, J., eds. (1998) Global Wetland Distribution and Functional Characterisation: Trace Gases and the Hydrologic Cycles. IGBP Report 46. Stockholm, Sweden: International Geosphere-Biosphere Programme.

Salo, J., Kalliola, R., Hakkinen, I., Makinen, Y., Niemala, P., Puhakka, M. \& Coley, P.D. (1986) River dynamics and diversity of Amazon lowland forest. Nature 322: 254-258.

Schiemer, F., Baumgartner, C. \& Tockner, K. (1999) Restoration of floodplain rivers: 'The Danube Restoration Project'. Regulated Rivers: Research and Management 15: 231-244. 
Schiemer, F., Keckeis, H., Reckendorfer, W. \& Winkler, G. (2001) The inshore 'retention concept' and its significance for large rivers. Archiv für Hydrobiologie, Supplement 135: 509-516.

Serageldin, I. (1999) Looking ahead: water, life and the environment in the twenty-first Century. Water Resources Development 15: 17-28.

Shatalov, V. (2001) The floodplain forests in the European part of the Russian federation. In: The Floodplain Forests in Europe, ed. E. Klimo \& H. Hager, pp. 185-201. Leiden, The Netherlands: Brill.

Schaeffer, J.R., Mullan, J.D. \& Hinch, N.B. (2002) Encouraging wise use of flood plains with market-based incentives. Environment 44: 33-43.

Shiklomanov, I.A. (1998) Assessment of water resources and water availability in the world. Report for the comprehensive assessment of freshwater resources of the world. New York, USA: United Nations.

Sienkiewicz, J., Kloss, M. \& Grzyb, M. (2001) The floodplain forest ecosystem in Poland. In: The Floodplain Forests in Europe, ed. E. Klimo \& H. Hager pp. 249-297. Leiden, The Netherlands: Brill.

Sippel, S.J., Hamilton, S.K., Melack, J.M. \& Novo, E.M.M. (1998) Passive microwave observations of inundation area and the area/stage relation in the Amazon River floodplain. International Fournal of Remote Sensing 19: 3055-3074.

Skagen, S.K., Melcher, C.P., Howe, W.H. \& Knopf, F.L. (1998) Comparative use of riparian corridors and oases by migrating birds in Southeast Arizona. Conservation Biology 12: 896-909.

Smits, A.J.M., Nienhuis, P.H. \& Leuven, R.S.E.W., eds. (2000) Nem Approaches to River Management. Leiden, The Netherlands: Backhuys Publisher.

Snyder, E. B., Eitemiller, D. J. Arango, C. P. Uebelacker, M. L. \& Stanford, J. A. (2002) Floodplain hydrologic connectivity and fisheries restoration in the Yakima River, USA. Verhandlungen der Internationalen Vereiningung für Theoretische und Angemandte Limnologie 28: (in press).

Spanjol, Z., Tikvic, I. \& Baricevic, D. (1999) Protected sites of floodplain forest ecosystems in the Republic of Croatia. Ekológia (Bratislava) 18: 82-90.

Sparks, R.E., Nelson, J.C. \& Yin, Y. (1998) Naturalization of the flood regime in regulated rivers. BioScience 48: 706-720.

Stanford, J.A. \& Ward, J.V. (1993) An ecosystem perspective of alluvial rivers: connectivity and the hyporheic corridor. Fournal of the North American Benthological Society 12: 48-60.

Stanford, J.A., Ward, J.V., Liss, W.J., Frissell, C.A., Williams, R.N., Lichatowich, J.A. \& Coutant, C.C. (1996) A general protocol for restoration of regulated rivers. Regulated Rivers: Research and Management 12: 391-413.

Stein, B.A. (2001) A fragile cornucopia assessing the status of US biodiversity. Environment 43: 11-22.

Stevens, L. E., Schmidt, J. C., Ayers, T. J. and Brown, B. T. 1995. Flow regulation, geomorphology, and Colorado River marsh development in the Grand Canyon, Arizona. Ecological Applications 5: 1025-1039.

Stiassny, M.L.J. (1996) An overview of freshwater biodiversity. Fisheries 21: 7-13.

Swales, S., Storey, A.W., Roderick, I.D. \& Figa, B.S. (1999) Fishes of floodplain habitats of the Fly River System, Papua New Guinea, and changes associated with El Niño draughts and algal blooms. Environmental Biology of Fishes 54: 389-404.

Tabacchi, E. \& Planty-Tabacchi, A.-M. (2000) Riparian plant community composition and the surrounding landscape: func- tional significance of incomers. In: Riparian Ecology and Management in Multi-Land Use Watersheds, ed. P.J. Wigington Jr \& R.L. Beschta, pp. 11-16. Corvallis, Oregon, USA: Proceedings of the AWRA's 2000 Summer Conference.

Thompson, J.R. (1996) Africa's floodplains: a hydrologic overview. In: Water Management and Wetlands in Sub-Saharan Africa, ed. M.C. Acreman \& G.E. Hollis, pp. 5-20. Gland, Switzerland: IUCN.

Tiker, G.M. \& Evans, M.I. (1997) Habitats for birds in Europe: a conservation strategy for the wider environment. Birdlife Conservation Series 6. Cambridge, UK: Birdlife International.

Timchenko, V., Oksijuk, O. \& Gore, J. (2000) A model for ecosystem state and water quality management in the Dnieper River delta. Ecological Engineering 16: 119-125.

Tockner, K. \& Ward, J.V. (1999) Biodiversity along riparian corridors. Archiv für Hydrobiologie, Supplement 115/3: 293-310.

Tockner, K., Baumgartner, C., Schiemer, F. \& Ward, J.V. (2000b) Biodiversity of a Danubian flood plain: structural, functional and compositional aspects. In: Biodiversity in Wetlands: Assessment, Function and Conservation, Vol. 1, ed. B. Gopal, W. Junk \& J.A. Davies, pp. 141-159. Leiden, The Netherlands: Backhuys Publishers.

Tockner, K., Malard, F. \& Ward, J.V. (2000a) An extension of the flood pulse concept. Hydrological Processes 14: 2861-2883.

Tockner, K., Malard, F., Burgherr, P., Robinson, C.T., Uehlinger, U., Zah, R. \& Ward, J.V. (1997) Physico-chemical characterization of channel types in a glacial floodplain ecosystem (Val Roseg, Switzerland). Archiv für Hydrobiologie 140: 433-463.

Tockner, K., Pennetzdorfer, D., Reiner, N., Schiemer, F. \& Ward, J.V. (1999) Hydrologic connectivity and the exchange of organic matter and nutrients in a dynamic river-floodplain system (Danube, Austria). Freshmater Biology 41: 521-535.

United Nations (1998) World Population Prospects: The 1998 Revision. New York, USA: United Nations Publications.

UNEP (2001) The Mesopotamian marshlands: demise of an ecosystem. Unpublished report. Nairobi, Kenya.

UNEP-WCMC (2001) Biodiversity and climate change [www document]. URL http://www.unep-wcmc.org/climate/impacts

UNESCO (1995) Discharge of Selected Rivers in Africa. Studies and Reports in Hydrology 52. Paris, France: UNESCO.

Van den Brink, F. W. B., Van der Velde, A., Buijse, A.D. \& Klink, A.G. (1996) Biodiversity in the Lower Rhine and Meuse riverfloodplains: its significance for ecological management. Netherlands Fournal of Aquatic Ecology 30: 129-149.

Van Dijk, G.M., Van Liere, L., Bannik, B.A. \& Cappon, J.J. (1994) Present state of the water quality of European rivers and implications for management. The Science of the Total Environment 145: 187-195.

Van der Nat, D., Schmidt, A., Edwards, P.J., Tockner, K. \& Ward, J.V. (2002) Inundation dynamics in braided flood plains (Fiume Tagliamento). Ecosystems (in press).

Vitousek, P.M., Mooney, H.A., Lubchenco, J. \& Melillo, J.M. (1997) Human domination of earth's ecosystems. Science 277: 494-499.

Vörösmarty, C.J., Green, P., Salisbury, J. \& Lammers, R.B. (2000) Global water resources: vulnerability from climate change and population growth. Science 289: 284-288.

Walter, T., Umbricht, M. \& Schneider, K. (1998) Datenbank zur Fauna der Auen. FAL, Reckenholz, Switzerland [www document]. URL http://www.admin.ch/sar/fal/aua/

Ward, J.V. \& Stanford, J.A. (1995) Ecological connectivity in 
alluvial river ecosystems and its disruption by flow regulation. Regulated Rivers: Research and Management 11: 105-119.

Ward, J.V., Tockner, K. \& Schiemer, F. (1999a) Biodiversity of floodplain river ecosystems: ecotones and connectivity. Regulated Rivers: Research and Management 15: 125-139.

Ward, J.V., Tockner, K., Arscott, D.B. \& Claret, C. (2002) Riverine landscape diversity. Freshmater Biology 47: 517-539.

Ward, J.V., Tockner, K., Edwards, P.J., Kollmann, J., Bretschko, G., Gurnell, A.M., Petts, G.E. \& Rosaro, B. (1999b) A reference river system for the Alps: The 'Fiume Tagliamento'. Regulated Rivers: Research and Management 15: 63-75.

Warne, A.G., Toth, L.A. \& White, W.A. (2000) Drainage-basinscale geomorphic analysis to determine reference conditions for ecologic restoration - Kissimmee River, Florida. GSA Bulletin 112: 884-899.

Welcomme, R.L. (1975) The fisheries ecology of African floodplains. CIFA Technical Paper 3. FAO, Rome, Italy.

Welcomme, R.L. (1979) Fisheries Ecology of Floodplain Rivers. London, UK: Longman.

Wenger, E.L., Zinke, A. \& Gutzweiler, K.-A. (1990) Present situation of European floodplain forests. Forest Ecology and Management 33/34: 5-12.

Wilcove, D.S., Rothstein, D., Dubow, J., Phillips, A. \& Losos, E. (1998) Quantifying threats to imperiled species in the United States. BioScience 48: 607-615.
Williams, W.D. (2002) Environmental threats to salt lakes and the likely status of inland saline ecosystems 2025. Environmental Conservation 29: 154-167.

Worldwatch Institute (2001) Vital Signs 2001. Washington DC, USA: Worldwatch Institute.

WWF (1999) Living Planet Report, ed. J. Loh, J. Randers, A. MacGillivray, V. Kapos, M. Jenkins, B. Groombridge, V. Cox \& B. Warren. Gland, Switzerland: WWF International.

WWF \& EU (2001) Implementing the EU Water Freshwater Directive. Seminar 2: The role of wetlands in river basin management. Unpublished report. Brussels, Belgium, 9-10 November 2000.

Yon, D. \& Tendron, G. (1981) Alluvial Forests of Europe. Brussels, Belgium: European Committee for the Conservation of Nature and National Resources.

Zavaleta, E. (2000) Valuing ecosystem services lost to Tamarix invasion in the United States. In: Invasive Species in a Changing World, ed. H.A. Mooney \& R.J. Hobbs, pp. 261-300. Washington DC, USA: Island Press.

Zong, Y. \& Chen, X. (2000) The 1998 flood on the Yangtze, China. Natural Hazards 22: 165-184.

Zwiers, F.W. \& Kharin, V. V. (1998) Changes in the extremes of the climate simulated by CCC GCM2 under $\mathrm{CO}_{2}$-doubling. Fournal of Climate 11: 2200-2222. 